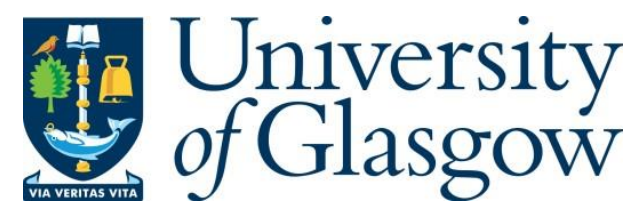

Ramos, D., Solana, J., Buckley, R. P., and Greenacre, J. (2016) Protecting mobile money customer funds in civil law jurisdictions. International and Comparative Law Quarterly, 65(3), pp. 705-739. (doi:10.1017/S0020589316000142)

There may be differences between this version and the published version. You are advised to consult the publisher's version if you wish to cite from it.

http://eprints.gla.ac.uk/128124/

Deposited on: 13 September 2016

Enlighten - Research publications by members of the University of Glasgow http://eprints.gla.ac.uk 


\title{
Protecting Mobile Money Customer Funds in CiviL LAW JURISDICTIONS
}

\author{
David Ramos* \\ Javier Solana $^{* *}$ \\ Ross P Buckley*** \\ Jonathan Greenacre
}

\begin{abstract}
The provision of financial services through mobile phones is a powerful tool to foster financial inclusion, and thus economic growth, in developing countries. However, it raises important regulatory issues. Given the vulnerability of most potential customers of these services, the protection of customer funds is important. In common law countries, trust accounts are an effective response to these concerns. In civil law jurisdictions however, in the absence of trusts, protection of customer funds is more difficult. This paper identifies the theoretical and practical problems that regulators in civil law jurisdictions might face when trying to protect customer funds and explores how fiduciary contracts, mandate contracts and direct regulation might be used to achieve this goal. It offers a series of practical recommendations for policy-makers in developing countries that provide a range of regulatory options that combine private law and regulation.
\end{abstract}

\section{Keywords:}

Digital financial services, mobile money, funds protection, fiduciary, mandate, trusts.

\footnotetext{
* Senior Lecturer of Commercial Law, Carlos III University of Madrid.

** DPhil Candidate in Law, University of Oxford.

*** CIFR King \& Wood Mallesons Professor of International Finance Law, Scientia Professor, and Member, Centre for Law Markets and Regulation, UNSW Australia.

**** DPhil Candidate in Law, University of Oxford.

The authors are grateful for comments on an earlier draft by an anonymous referee which improved the final version.. Remaining errors are our own.
} 


\section{$\underline{\text { Table of Contents }}$}

I. Introduction Error! Bookmark not defined.

II. E-money: Transaction Structure and Risks for Customers' Funds ..................5

A. The structure of an e-money transaction ......................................................................5

B. Risks to customers' funds, and legal "functions". How the common law fulfils the

functions and what are the challenges for civil law systems...................................................8

C. The problem in legal terms: default rules and mandatory rules .................................12

Deleted

III. The Protection Of Customers' Funds In Civil Law Jurisdictions: A

Combination Of Different Legal Instruments..................................................... 16

A. Proprietary alternatives: the fiduciary transaction ............................................................17

1. Basic transaction

2. Fulfilment of functions ....

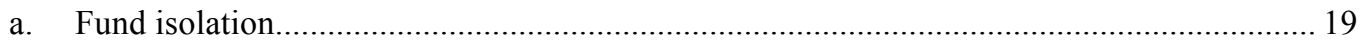

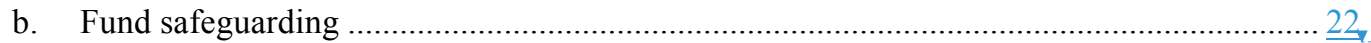

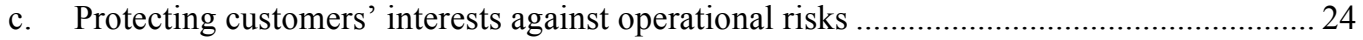

B. Contractual/obligational alternatives: the mandate contract ......................................26,

C. Regulatory alternatives: regulating functional duties directly and/or requiring insurance

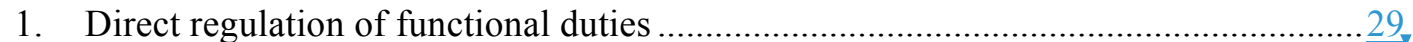

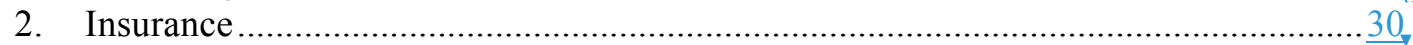

IV. A Roadmap of Legal Strategies for E-Money .................................................33

A. A summary of the options available to regulators ............................................................33

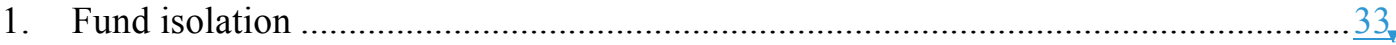

2. Fund safeguarding and protection of customers' interests .......................................36,

B. How can legislatures grant protection while fostering competition between

different e-money models and ensuring cross-border compatibility? .................................38

C. Other variables shaping regulation of e-money: supervisory capacity and

customers' vulnerability

1. Supervisory capacity

2. Customers' vulnerability

V. Conclusion

Deleted

Deleted

Deleter

Deleter

Deleted:

Deleted

Deleteı

Deleter

Deleted

Deleted

Deleter

Deleter

Deleted: 


\section{INTRODUCTION}

More than half of the adults in the world have no access to basic financial services. ${ }^{1}$ Instead, they rely on informal mechanisms for saving and protecting themselves against risk, such as pawning possessions, buying livestock as a means of saving, and using moneylenders for credit. ${ }^{2}$ Such measures are often both risky and expensive. ${ }^{3}$

Mobile money facilitates access to financial services. Mobile money can be broadly defined as the use of mobile networks to receive financial services and execute financial transactions. ${ }^{4}$ Typically, this is done through the storage of electronic money ("e-money") units in servers that can be accessed through a mobile phone.

The combination of e-money and mobile technology allows consumers to benefit from the wide coverage of mobile network operators ("MNOs"). This has helped to improve the lives of many people in developing countries by providing access to financial services while reducing cost and improving security. ${ }^{5}$

Mobile money continues to promote financial inclusion. ${ }^{6}$ At the end of 2014 , sixteen markets already had more mobile money accounts than bank accounts, compared to nine in $2013 .^{7}$ There are more than 103 million active mobile money accounts globally with 255 services in 89 countries, with a particularly strong presence in Sub-Saharan Africa, and expansion expected in other developing regions. ${ }^{8}$

\footnotetext{
${ }^{1}$ See Michael J Casey, 'World's "Unbanked” En Route to Financial Inclusion With Mobile Money' (Money Beat, 5 November 2014) <http://blogs.wsj.com/moneybeat/2014/11/05/worlds-unbanked-en-route-to-financialinclusion-with-mobile-money/> accessed 14 November 2014.

${ }^{2}$ The Consultative Group to Assist the Poor, 'Financial Inclusion' (Financial Inclusion)

$<$ http://www.cgap.org/topics/financial-inclusion> accessed 13 November 2014.

${ }^{3}$ ibid.

${ }_{5}^{4}$ See Alliance for Financial Inclusion, ‘Mobile Financial Services: Basic Terminology’ (2013) 1.

${ }^{5}$ See World Bank, 'Kenya Economic Update: Kenya at the Tipping Point? With a Special Focus on the ICT Revolution and Mobile Money' (2010) 23.

${ }^{6}$ Financial inclusion means affordable access to financial services. See The Consultative Group to Assist the Poor (n 2).

${ }^{7}$ See Claire Scharwatt and others, 'State of the Industry 2014: Mobile Financial Services for the Unbanked' (GSMA, 2015) 26.

${ }^{8}$ In 2014, 53 per cent of live mobile money services were in Sub-Saharan Africa. However, half of all new launches occurred outside that region, most notably in Latin America and the Caribbean, East Asia and the Pacific and South Asia. Competition is also increasing: see ibid 14-16.
} 
As mobile money grows, some questions will become more pressing: Are customers' funds sufficiently protected against theft or the insolvency of their e-money provider; and are proper regulatory frameworks in place for the MNO's custody and management obligations?

In 2014, two of us published an article where we proposed the use of trust law to protect mobile money customer funds in common law jurisdictions. ${ }^{9}$ Many civil law countries offer great potential for increased financial inclusion through the use of mobile money. ${ }^{10}$ Although fund protection is a pressing issue in civil law countries, it is less readily resolved than under the common law. Some jurisdictions have tried to replicate the effects of the common law trust with local legal structures, there being no exact equivalent in civil law jurisdictions. ${ }^{11}$ Whether precise replication is possible, or even desirable, is beyond the scope of this paper. ${ }^{12}$

Whereas the common law trust regulates both rights in personam (e.g. customer rights against the provider of e-money services) and rights in rem (e.g. customer rights over funds), the civil law makes a sharp distinction between the Law of Obligations (for rights in personam) and the Law of Property or "Real" Rights (for rights in rem). Consequently, legal institutions conceived to regulate one type of right may fall short on other rights. Providing emoney customers in civil law countries with similar protection to that provided by the common law trust requires analysis of different legal mechanisms. The complexity of this challenge determines the structure of the present article.

\footnotetext{
${ }^{9}$ See Jonathan Greenacre and Ross P Buckley, 'Using Trusts to Protect Mobile Money Customers' (2014) 2014 Singapore Journal of Legal Studies 59.

${ }^{10}$ Excepting Belize and Guyana, all countries in Latin America have a civil law tradition, as do the majority of countries in Africa and South East Asia. See Maurizio Lupoi, Trusts: A Comparative Study (Cambridge University Press 2000) ch 5.

${ }^{11}$ See eg François Barrière, 'The French Fiducie, or the Chaotic Awakening of a Sleeping Beauty' in Lionel D Smith (ed), Re-imagining the trust : trusts in civil law (Cambridge University Press 2012); Dante Figueroa, 'Civil Law Trusts in Latin America: Is the Lack of Trusts an Impediment for Expanding Business Opportunities in Latin America?' (2007) 24 Arizona Journal of International and Comparative Law 701.

${ }^{12}$ The question of how to fit trusts in civil law jurisdictions has been extensively debated. See eg MJ de Waal, 'In Search of a Model for the Introduction of Trusts into a Civilian Context' (2001) 12 Stellenbosch Law Review; Tony Honoré, 'On Fitting Trusts into Civil Law Jurisdictions' (2008) 27/2008 $<$ http://ssrn.com/abstract=1270179>.
} 
Section II describes the basic structure of an e-money transaction and identifies the main functions that a desirable legal mechanism would need to fulfil to protect e-money customers' funds effectively. We also describe how the common law trust fulfils those functions and why protecting e-money customers' funds in a civil law jurisdiction will require the analysis of different legal mechanisms.

Section III develops the inquiry in civil law jurisdictions, drawing on examples from both developed and developing countries. ${ }^{13}$ The purpose is to develop a "civil law benchmark" of legal institutions that (1) could constitute a firm basis for e-money, and (2) could be compatible with the civil law tradition, broadly understood. This Section explores two legal mechanisms: one rooted in the Law of Property (the fiduciary contract) and another one rooted in the Law of Obligations (the mandate contract). Neither mechanism fulfils all necessary functions by itself. Nevertheless, regulators could try to combine them to fill the relevant gaps by enacting legislation. Alternatively, they could rely on insurance contracts as a fall-back option to cover the risks that e-money customers face.

Section IV explores different strategies available to regulators and discusses a series of issues to bear in mind when attempting to protect customers' funds through regulation. The interaction of new regulations with existing legal rules could hinder competition between different providers or make cross-border recognition more difficult. Insufficient resources and customers' vulnerability could also limit the effective implementation of any regulation. Section V concludes.

II. E-MONEY: TRANSACTION STRUCTURE AND RISKS FOR CUSTOMERS' FUNDS

\section{A. The Structure of an E-money Transaction}

\footnotetext{
${ }^{13}$ We have selected developed countries that represent different approaches to the accommodation of common law trusts and developing countries where regulations of e-money services already exist.
} 
Mobile money involves the transfer of e-money through mobile phones. E-money is typically defined as stored monetary value which is represented by a claim on the issuer and issued on receipt of funds for the purpose of making payment transactions and accepted by a person other than the issuer. ${ }^{14}$

Different countries have developed different e-money business models, largely dependent on the type of entities providing the e-money service ("Providers"). Different business models can be classified depending on the level of involvement of banks and nonbank institutions.

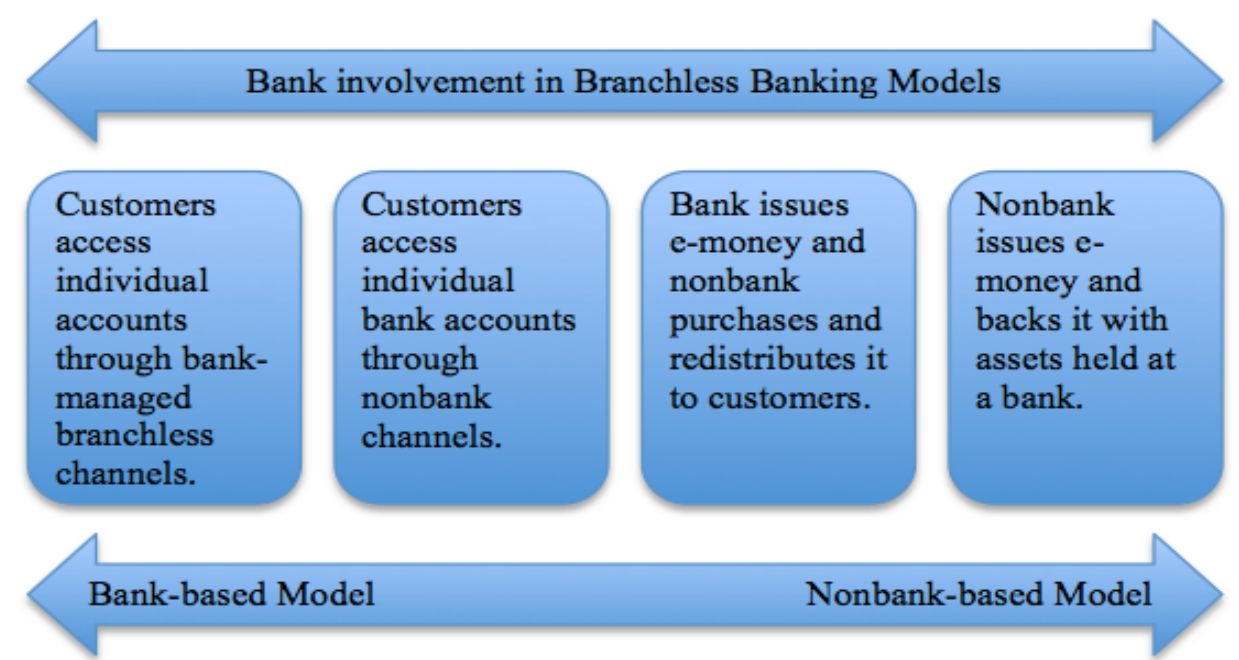

Graphic 1. Bank-based versus non-bank-based models ${ }^{15}$

In a bank-based model, customers have a direct contractual relationship with a bank, or with a non-bank agent contracting on behalf of a bank. ${ }^{16}$ In some of these cases the

\footnotetext{
${ }^{14}$ See Directive 2009/110/EC of 16 September 2009 on the taking up, pursuit and prudential supervision of the business of electronic money institutions (hereinafter, the "E-Money Directive"), art 2.

${ }^{15}$ Based on Michael Tarazi and Paul Breloff, 'Nonbank E-Money Issuers: Regulatory Approaches to Protecting Customer Funds' (CGAP Focus Note, 2010) 2.

${ }^{16}$ In many developing countries, bank branches are not widespread. They can use the agency network of MNOs to reach out to potential customers.
} 
services have been characterized as bank deposits, subject to deposit guarantee, ${ }^{17}$ and restricted to institutions with a banking license. ${ }^{18}$

In nonbank-based models, customers do not have a direct relationship with a bank, and thus do not need a bank account to make financial transactions. ${ }^{19}$ In several developing countries, MNOs have become important non-bank Providers of e-money services. ${ }^{20}$ Users buy a SIM card with the mobile money application for their phone, which has an electronic account associated to it. The non-bank Provider issues electronic value that customers purchase with legal tender, which the Provider will often store in a bank account. Customers can use this mechanism to deposit money into ("cash in") or withdraw money from ("cash out") their account. They will normally do so through specific access points such as agents of the Provider or Automated Teller Machines (ATMs). They can also use their mobile phone applications to send money to or receive money from other service users. The aggregate balance in each user's account is referred to as the "customers' funds". ${ }^{21}$ The model is depicted in the diagram below.

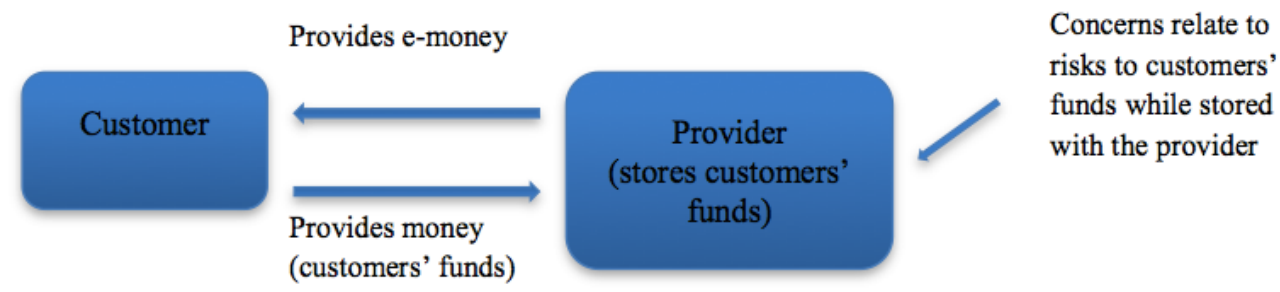

Graphic 2. Basic mobile e-money model $^{22}$

\footnotetext{
${ }^{17} \mathrm{Eg}$ in the case of Colombia, see Ley de Inclusión Financiera de 4 de junio de 2014, art 1.

${ }^{18}$ This is the case in Colombia and Mexico. See Alliance for Financial Inclusion, 'Regulatory Approaches to Mobile Financial Services in Latin America' (2014) 5-7.

${ }^{19}$ This excludes internet-based payment systems such as PayPal, which require bank accounts.

${ }^{20}$ Eg Paraguay: see Resolución n ${ }^{\circ} 6$ del Banco Central de Paraguay (BCP), de 13 de marzo de 2014, which establishes the Reglamento de Medios de Pago Electrónicos (hereinafter, "Paraguayan E-Payments Regulation").

${ }^{21}$ This description is based on the highly successful M-PESA service in Kenya. See Michael Klein and Colin Mayer, 'Mobile Banking and Financial Inclusion: The Regulatory Lessons' (World Bank Policy Research Working Paper 5664, 2011) 7-10.

22 Jonathan Greenacre and Ross Buckley, 'Trust Law Protections for E-Money Customers: Lessons and a Model Trust Deed Arising from Mobile Money Deployments in the Pacific Islands' (2013) $8<$ http://www.afiglobal.org/sites/default/files/publications/piwg_knowledge_product_emoney_trust_and_model_trust_deed.pdf $>$ accessed 13 November 2014 .
} 
Given the limited scope of banks in developing countries, particularly in rural areas, the provision of e-money services by non-bank institutions has great potential for fostering financial inclusion. However, it also brings legal challenges for the protection of customers' funds: in these cases, e-money will normally be characterized as a sui generis financial product and thus will not be covered by protection mechanisms applicable to more traditional financial products such as deposit insurance. This paper explores how civil law jurisdictions can address these challenges.

\section{B. Risks to Customers' Funds, and Legal "Functions": How the Common Law Fulfils the Functions and What the Challenges are for Civil Law Systems}

There are three main risks to customer funds that occur as a result of the transaction structure outlined above. These risks determine the functional characteristics required for any legal solution to be effective.

First, if the e-money Provider or bank where the Provider holds its customers' funds becomes insolvent, customers bear the risk of not being able to recover their funds ("insolvency risk"). The funds may be used to repay privileged creditors, or distributed pari passu among ordinary creditors of the insolvent institution. Any legal mechanism aiming to protect customers' funds from insolvency must therefore fulfil the function of "fund isolation". ${ }^{23}$ This type of protection raises three issues:

- whether the legal mechanism employed has the effect of segregating customers' assets from the assets of the Provider if the latter becomes insolvent;

\footnotetext{
${ }^{23}$ The term "fund isolation" is often used in the context of mobile money services. See Alliance for Financial Inclusion (n 4) 3.
} 
- if the assets backing the customers' accounts are held in a financial institution, whether those assets will be protected from the insolvency of the institution; ${ }^{24}$

- whether customers will have preferential rights over separate assets, or pro-rata rights over a single asset pool (segregated from the Provider's and the bank's assets).

Second, customers may not be able to cash out their e-money accounts upon request ("liquidity risk"), if the ratio between e-money issued and customers' funds is greater than 1:1. Regulation should thus safeguard customers' funds by constraining the Provider from using those funds for its own purposes. This function is closely connected to fund isolation.

Third, customers' funds may be lost due to "operational risks" such as fraud, theft, misuse, negligence or poor administration. ${ }^{25}$

The response to these risks in common law countries is closely associated with the legal institution of the trust. Two of us have proposed that a trust relationship could protect emoney customers against these risks: the Provider could act as trustee of the customers' funds (i.e. trust assets) for the benefit of the customers (i.e. "beneficiaries").

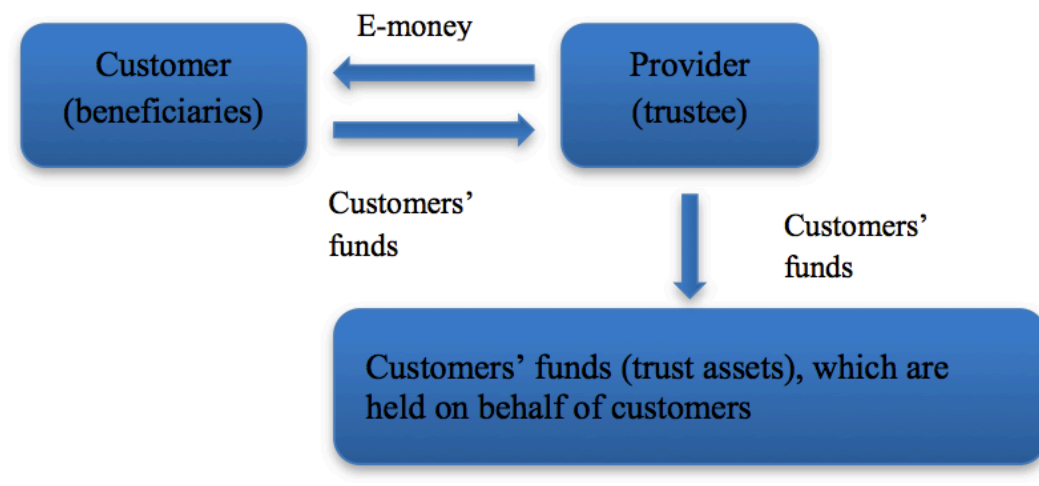

Graphic 3. The application of a common law trust to e-money ${ }^{26}$

\footnotetext{
${ }^{24}$ We can expect MNOs to hold securities in an account with a securities intermediary that will have an account at the central securities depository.

${ }^{25}$ See Greenacre and Buckley (n 9) 63-65. There have been recent concerns with the possibility of customers' funds being stolen while stored with the Provider. In 2012, workers at the telecommunications provider MTN in Uganda stole 15 billion Ugandan shillings. See Jeff Mbanga, 'How MTN Lost Mobile Billions' (The Observer, 24 May 2014) <http://www.observer.ug/index.php?option=com_content\&view=article\&id=18921:how-mtnlost-mobile-billlions> accessed 14 November 2014.

${ }^{26}$ See Greenacre and Buckley (n 22) 10.
} 
The features of the trust fit the mobile money industry well. ${ }^{27}$ A trust can fulfil the previous functions, and protect against (at least some of) the customers' risks in holding emoney. First, a trust isolates customers' funds from other assets held by the Provider. Typically, the Provider is the legal owner of the customers' funds because these are kept in one or more accounts in the name of the Provider, not the customers' ${ }^{28}$ However, the assets are held in a separate account where customers are the beneficiaries. ${ }^{29}$ Isolation from the financial institution's insolvency, and segregation of customer accounts, may be a more complex issue, and will depend on whether the Provider accounts are also trust accounts.

Second, trust law can safeguard customers' funds from liquidity risk. Trustee duties can either be explicit (in the contract) or implied (by law) ${ }^{30}$ and may require the provider/trustee to maintain a 1:1 ratio between e-money and funds on deposit in the trust account; invest customers' funds in liquid assets; diversify its portfolio; and prevent it from using customer funds for its own purposes. ${ }^{31}$

Third, trusts can be used to minimize operational risk in two ways. The trust deed can require the Provider to have the trust accounts audited regularly; and can provide for a third party (typically the relevant regulator) to serve as the Protector and monitor the Provider's compliance with its duties as trustee as customers may not have the capacity to monitor the trustee themselves. $^{32}$

\footnotetext{
${ }^{27}$ For a thorough analysis of the general principles of trusts law, see Geraint W Thomas and Alastair Hudson, The Law of Trusts (2nd edn, Oxford University Press 2010).

${ }^{28}$ See Greenacre and Buckley (n 9) 64.

${ }^{29}$ Trusts law has an important distinction between legal ownership and beneficial ownership that should be carefully considered.

${ }^{30}$ See Greenacre and Buckley (n 9) 68.

${ }^{31}$ See ibid 67.

${ }^{32}$ See ibid 70 .
} 


\begin{tabular}{|l|l|l|l|}
\hline \multicolumn{1}{|c|}{ Function } & \multicolumn{1}{|c|}{ Specification } & \multicolumn{1}{|c|}{ Issue } & \multicolumn{1}{c|}{ Trust } \\
\hline Fund isolation & $\begin{array}{l}\text { Segregation from } \\
\text { the Provider's } \\
\text { funds }\end{array}$ & $\begin{array}{l}\text { If the Provider goes insolvent, can } \\
\text { customers separate their assets } \\
\text { from the insolvent estate? }\end{array}$ & $\begin{array}{l}\text { Achieved if a trust is used } \\
\text { and customers are } \\
\text { beneficiaries }\end{array}$ \\
\cline { 2 - 5 } & $\begin{array}{l}\text { Segregation from } \\
\text { the financial } \\
\text { institution's funds }\end{array}$ & $\begin{array}{l}\text { If the financial institution goes } \\
\text { insolvent, can customers separate } \\
\text { their assets from the insolvent } \\
\text { estate? }\end{array}$ & $\begin{array}{l}\text { Depends on whether the } \\
\text { Provider's accounts are } \\
\text { trust accounts }\end{array}$ \\
\cline { 2 - 5 } & $\begin{array}{l}\text { Segregation from } \\
\text { other customers' } \\
\text { funds }\end{array}$ & $\begin{array}{l}\text { If either the Provider or financial } \\
\text { institution goes insolvent, does } \\
\text { the individual customer have a } \\
\text { claim over specific assets, or do } \\
\text { customers have a collective claim } \\
\text { over an asset pool? }\end{array}$ & $\begin{array}{l}\text { Depends on the terms of } \\
\text { the trust structures }\end{array}$ \\
\hline $\begin{array}{l}\text { Fund } \\
\text { safeguarding }\end{array}$ & Liquidity & $\begin{array}{l}\text { Can the Provider or the financial } \\
\text { institution dispose of the } \\
\text { customer's funds? }\end{array}$ & $\begin{array}{l}\text { Explicit duties included in } \\
\text { the trust deed, backed by } \\
\text { fiduciary duties implied } \\
\text { by law }\end{array}$ \\
\hline interests & Fiduciary duties & $\begin{array}{l}\text { Do the Provider or the financial } \\
\text { institution have a duty to act in } \\
\text { the interest of the client when } \\
\text { managing the client's account? }\end{array}$ & $\begin{array}{l}\text { Explicit duties included in } \\
\text { the trust deed, backed by } \\
\text { fiduciary duties implied } \\
\text { by law }\end{array}$ \\
\hline
\end{tabular}

Table 1. Functions for the protection of mobile money customers

Civil law countries raise more difficult issues, as there is no "civil law trust". The most obvious reason for this is that the trust originated as a device to separate a specific asset, or group of assets, from the assets of the fiduciary, while facilitating the management of those assets by that fiduciary. Thus, trusts blur the line between bilateral obligations and property rights in a very "un-civilian way". 33

Such incompatibility is far from widely accepted, however. ${ }^{34}$ Legal structures such as the fiducie in France and the fideicomiso in Latin American jurisdictions have often been regarded as the civil law equivalent of, or at least as bearing a close resemblance to, common

\footnotetext{
${ }^{33}$ Lionel D Smith, 'The Re-Imagined Trust' in Lionel D Smith (ed), Re-imagining the trust : trusts in civil law (Cambridge University Press 2012) 258.

${ }^{34}$ Some scholars argue the differences are relatively unimportant and that there are ways of adapting trusts to civil law jurisdictions, as has occurred in Scotland and South Africa. For an analysis of the suitability of trusts in civil law jurisdictions, see eg de Waal (n 12) 66.
} 
law trusts. ${ }^{35}$ Furthermore, trusts set up in common law countries can be subject to recognition by means of the Hague Convention of 1985 on the Law Applicable to Trusts and on their Recognition ("the Hague Trusts Convention"), although very few states have ratified the Convention. $^{36}$

The second, and less obvious, reason is that the Anglo-Saxon trust has evolved over centuries and its contours and tenets are well established and readily enforced across common law jurisdictions. The legal term "trust" is easily recognizable, and associated with a series of rights and safeguards which are common across common law jurisdictions. This degree of consistency cannot be taken for granted for all private law institutions in civil law countries.

Thus, the quest is not for an equivalent of the trust, but for an institution, or combination of institutions, which can serve customers' needs in the specific context of emoney, be sufficiently recognizable to be readily enforceable, and provide adequate rules to accommodate evolving situations. We now proceed to explain the relevance of such "recognizability" and rules.

\section{C. $\quad$ The Problem in Legal Terms: Default Rules and Mandatory Rules}

This sub-section examines two types of legal rules that fulfil the above functions required to limit the risks to e-money customers: "mandatory rules" and "default rules". Both common law and civil law jurisdictions recognize freedom of contract and pacta sunt servanda (i.e. that the terms agreed upon in a contract will be enforced by the courts). However, there are instances where the solution enforced by the courts may be "contrary to", or "outside" what

\footnotetext{
${ }^{35}$ In France and in many Latin American jurisdictions, these approximations aim at improving the appeal of certain jurisdictions to foreign investors, particularly from England and the US. See Barrière (n 11); Figueroa (n $11)$.

${ }^{36}$ The most relevant civil law country to have ratified the Convention is Italy. See Michele Graziadei, 'Recognition of Common Law Trusts in Civil Law Jurisdictions under the Hague Trusts Convention with Particular Regard to the Italian Experience' in Lionel D Smith (ed), Re-imagining the trust : trusts in civil law (Cambridge University Press 2012).
} 
the parties have agreed. Solutions "contrary to" the agreement are contained in mandatory rules, and solutions "outside" what the parties have agreed are contained in default rules. ${ }^{37}$

The rationale for mandatory rules is difficult to apply in each case, but easy to explain. A strict enforcement of the terms of the contract in full presumes that (a) the parties are rational, (b) that they are fully informed, and (c) that all parties whose interests are at stake are involved. Regarding (a) and (b), mobile money customers may lack financial experience or financial education. Fully enforcing the terms of the contract could thus lead to results that are inefficient, in terms of resource allocation, or be seen as unfair.

The rationale for default rules is subtler, yet even more important, as even very sophisticated Providers cannot foresee all possible contingencies. Courts will enforce contract terms as a "plan A", but default rules act as a "plan B", in case a contingency arises that is not covered by the contract.

Civil law courts first try to ascertain the contract's "meaning" or the parties' "wishes", ${ }^{38}$ but at times are required to resort to default rules. To select the most suitable default rules civil law judges try to subsume the facts into one of the existing categories of legal transactions, by asking the following kind of question:

Which of the relationships envisaged in the law that have an element of custody or safeguarding (deposit, mandate, etc.) most closely resembles the relationship the Provider has with its customer? $?^{39}$

\footnotetext{
${ }^{37}$ Default rules fill the gaps in incomplete contracts. They govern unless parties contract around them by prior agreement. See Ian Ayres and Robert Gertner, 'Filling Gaps in Incomplete Contracts: An Economic Theory of Default Rules' (1989) 99 The Yale Law Journal 87, 87.

${ }^{38}$ See eg arts $1281-1288$ of the Spanish Civil code.

${ }^{39}$ Civil codes provide complete sets of 'default rules'. These default rules may be contained in (1) the general part of the Law of Contracts (as in France or Spain, and the codes inspired by them) and/or in the general part on the Law of Obligations (as in Germany); or (2) in the parts of the codes dedicated to the specific 'types' of contracts (sales, services, mandate, etc). This makes the 'classification' or 'qualification' of the contract a previous first step in order to determine which default rules are applicable. From a practical perspective, Spanish courts constantly resort to this technique to determine the default rules applicable to atypical contracts. As a recent example, see the decision of the Spanish Supreme Court of 24 October 2014 (RoJ 4811/2014) to
} 
Judges will have to choose between rules for fiduciary transactions, mandates, deposits or loans as default rules, which may result in different degrees of protection depending on the chosen institution.

The process followed by a civil law judge is summarized in the following decision tree:

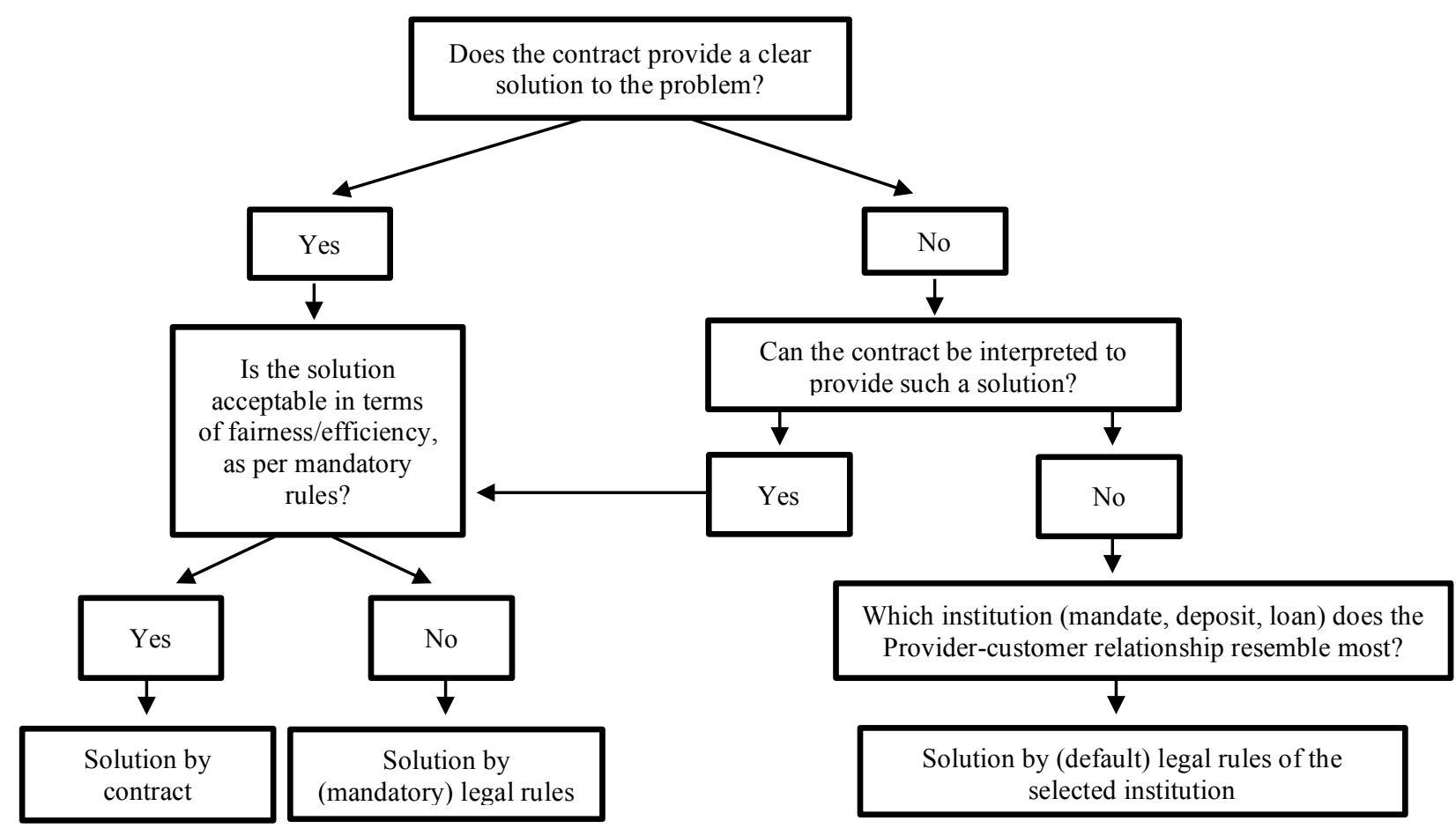

Bearing this in mind, a Provider could simply steer clear of mandatory rules, and try to draft the contract in terms that not only stipulate the explicit solutions to specific problems, but also broader, background rules, to cover unexpected contingencies. However, this decision tree does not sufficiently take into account two important factors.

determine the 'nature' of an escrow account contract. From an academic perspective, the technique is quite marked in the French tradition. See e.g. Xavier Henry La Technique des Qualifications Contractuelles Thèse de doctorat, Université de Nancy, 1992 pp. 50-76, who puts this technique in relation with general concepts, such as the objet, or the cause of the contract. See also J. F. Overstake "Essai de classification des contrats spéciaux" LGDJ (1969) pp. 12 et seq, or Pascal Frechette "La qualification des contrats: aspects théoriques" Les Cahiers de Droit Vol. $51 \mathrm{n}^{\mathrm{o}} 1$ (2010), pp. 117-158, who also studies the approach under the Laws of Quebec. In Germany, the specific rules for each type of contract are construed as default rules, which require a previous classification. See Basil Markesinis; Hannes Unberath; Angus Johnson The German Law of Contract Second edition, Oxford: Hart Publishing (2006) pp. 138-144, 162-164. 
First, it does not acknowledge that it is a judge who decides whether there is a clear solution in the contract, or whether the contract can be interpreted to provide such a solution. A judge is not a contracting party, nor "neutral" about her preferences between "contract solutions" and "legal solutions". In case of conflicting interpretations of the contract the judge may be tempted hold that the contract was not clear enough to derogate from the legal rules she knows. ${ }^{40}$

Second, in civil law countries this tendency to resort to the default rules of existing institutions is often reinforced by the doctrine of the causa. Causa resembles common law consideration but has further implications and, under some views, requires a judgment of correspondence or adequacy between the socio-economic function of the contract, and the socio-economic function of one of the contract "types" (deposit, mandate or loan). ${ }^{41}$ In the absence of a contractual provision, courts will tend to use the rules of the institution relied upon by the parties, as default rules.

In exercising in personam jurisdiction resulting from the Provider-customer agreement, this exercise may simply result in a more obstinate reliance by courts on legal institutions, rather than contract terms. However, in relation to fund isolation, the available

\footnotetext{
${ }^{40}$ Common law judges are also prone to such biases. Law-and-economics scholars suggest that generally courts tend to require parties to have reached a "sufficient" agreement to derogate from default rules, and often use a strict interpretation of the sufficiency of the agreement in a way that turns default rules into something closer to mandatory rules. See Ayres and Gertner (n 37) 120-123; Charles J Goetz and Robert E Scott, 'The Limits of Expanded Choice: An Analysis of the Interactions between Express and Implied Contract Terms' (1985) 73 California Law Review 261, 263; Alan Schwartz and Robert E Scott, 'Contract Theory and the Limits of Contract Law' (2003) 113 The Yale Law Journal 541, 564 et seq. In civil law countries courts may be even more prone to this exercise due to the confluence of 'specific' default rules (e.g. the rules of the different contract types, such as sale, mandate, deposit, etc) and 'general' default rules, which may constitute an autonomous source of obligations, such as the duty of good faith. Such open textured provisions can be a source of uncertainty in some civil law countries. For a reference to the German law tradition, see Basil Markesinis; Hannes Unberath; Angus Johnson The German Law of Contract cit. pp. 119-133.

${ }^{41}$ Some view the causa as a basic requirement of validity, like common law consideration, though in reality the concept is the pivot to evaluate the validity of the contract pursuant to its finality, or (under some "objectivistic" views of the causa) economic function. See Luis Díez-Picazo, Fundamentos Del Derecho Civil Patrimonial (vol I, Thomson Civitas 2007) 266-285.
} 
structures of rights in rem under a civil code may result in the invalidity of the customer's claim over the funds, since, for rights in rem the doctrine of numerus clausus prevails. ${ }^{42}$

If the structure of rights envisaged in the contract and those envisaged in one of the legal institutions contemplated in the civil codes do not correspond, it can create friction between the law and the goals of the contract (at best), or render the customer's rights over the funds ineffective against Provider's creditors (at worst). It is therefore critical to analyse the structure of rights in the existing figures contemplated under the civil codes. That is the purpose of Section III.

\section{THE PROTECTION OF CUSTOMERS` FUNDS IN CIVIL LAW}

\section{JURISDICTIONS: A COMBINATION OF DIFFERENT LEGAL INSTRUMENTS}

Civil law systems distinguish between rights in personam and rights in rem. Different legal instruments provide the default rules (and some mandatory rules) for the customer-Provider relationship, while other instruments provide rules for the relationship of the customer with the funds. On this basis, we examine "proprietary alternatives" (mainly the rules on fiduciary transactions introduced in some civil law countries) (A), and then "contractual/obligational alternatives" (mainly the rules on mandate) (B). The former falls short on remedies against the Provider, whereas the latter falls short of proprietary protections. We therefore also examine the possibility of specific regulatory interventions $(\mathrm{C})$ that define e-money as a type of relationship of its own, similar to what has been done in the case of other financial transactions.

\footnotetext{
${ }^{42}$ Under this doctrine, there must be a closed number of rights receiving privileged protection against third parties. A party cannot grant another party privilege over assets (right in rem) without good reason (causa). If the parties create a privilege outside the rights in rem contemplated by the law, or use a right in rem protected by the law in a way incompatible with its function, the arrangement may be held invalid. If the arrangement is held valid, the gaps left by the parties will be filed by the default rules of the specific right in rem. See Luis DíezPicazo, Fundamentos Del Derecho Civil Patrimonial (vol III, Thomson Civitas 2008) 131 et seq.
} 


\section{A. $\quad$ Proprietary Alternatives: The Fiduciary Transaction}

\section{Basic transaction}

Perhaps the legal instrument that bears the closest resemblance to the trust in a civil law jurisdiction is the fiducia. ${ }^{43}$ The fiducia encompasses a wide array of applications. Some jurisdictions regulate fiducia expressly; others only recognize it but do not have express legal provisions to regulate it; while some jurisdictions do not recognize it at all. Moreover, where the fiducia is recognized, it may be referred to by different names; and, even among those using the same name, its legal structure and effects may vary across jurisdictions. ${ }^{44}$ It may be recognized as a product of the parties' free will ${ }^{45}$ or may arise by operation of the law. ${ }^{46}$ The formalities required for its constitution may be more or less stringent. It may be limited to commercial transactions, or it may cover a broader range of situations, including successions, tax and charitable purposes. ${ }^{47}$ Some jurisdictions may also impose restrictions on who has capacity to act as fiduciary. ${ }^{48}$

This paper focuses on applications of fiducia that are achieved by an inter vivos deed.

We will refer to them as "fiduciary transactions". A fiduciary transaction can be broadly defined as an arrangement under which one party - the settlor - conveys property to another

\footnotetext{
${ }^{43}$ There are seemingly two legal traditions. The "Roman fiducia" limits the power of abuse of the fiduciary by the negative binding obligation. By contrast, in the "Germanic fiducia" any use contrary to the end sought results in the return of the object to the settlor or the settlor's heirs, even if it negatively impacts a third purchaser: Sergio Cámara Lapuente, 'Trusts in Spanish law' in Madeleine Cantin Cumyn (ed), Trust vs Fiducie in a business context (Bruylant 2000) 197. Common law trusts and civil law fiduciary instruments may have a common base in the Roman-Canonical usus. See de Waal (n 12) 65; Lupoi (n 10) 185. However, it is generally understood that the beneficiary under a fiducia is not equivalent to the beneficiary under a trust. For a detailed analysis of the fiducia and the common law trust, see Figueroa (n 11) 4-7, 23-32; Rafael Sánchez Aristi, Property and Trust Law in Spain (2nd edn, Kluwer Law International 2014) para 243.

${ }^{44}$ For an overview of the differences in different jurisdictions, see Barrière (n 11); Lupoi (n 10) 273-291; Madeleine Cantin Cumyn, 'Reflections Regarding the Diversity of Ways in Which the Trust Has Been Received or Adapted in Civil Law Countries' in Lionel D Smith (ed), Re-imagining the trust: trusts in civil law (Cambridge University Press 2012).

${ }^{45}$ See eg Cámara Lapuente (n 43) 195-198.

${ }^{46}$ See eg French Civil Code, art 2012.

${ }^{47}$ See eg Ley 17.703, signed into law on 4 November 2003, regulating fideicomiso in Uruguay (hereinafter, "Uruguayan Fideicomiso Act").

${ }^{48}$ Usually banks and other authorized financial institutions. See eg Luxembourg Fiduciary Contracts Act, art 4; art 2015 of the French Civil Code; art 385 of Mexico's General Act on Credit Transactions; or art 5 of Argentinian Act 24.441.
} 
- the fiduciary - and the latter agrees to use that property for a specific purpose. The fiduciary agrees to transfer the fiduciary assets to one or more beneficiaries upon fulfilment of the agreed purpose. ${ }^{49}$ When using the fiduciary assets, the fiduciary will be subject to a series of duties agreed upon with the settlor or determined by law.

Generally, fiduciary contracts fulfil two purposes: a) the administration of the fiduciary assets by the fiduciary; and b) the provision of security for one or more obligations of the settlor. The use of fiduciary contracts in the context of e-money services would normally fall within the first category. Typically, in order to guarantee that customers will be able to recover their funds, the Provider will settle a fiduciary contract by transferring the funds to a fiduciary institution that will hold the assets for the benefit of the customers (i.e. the beneficiaries). ${ }^{50}$ Graphic 4 depicts this situation.

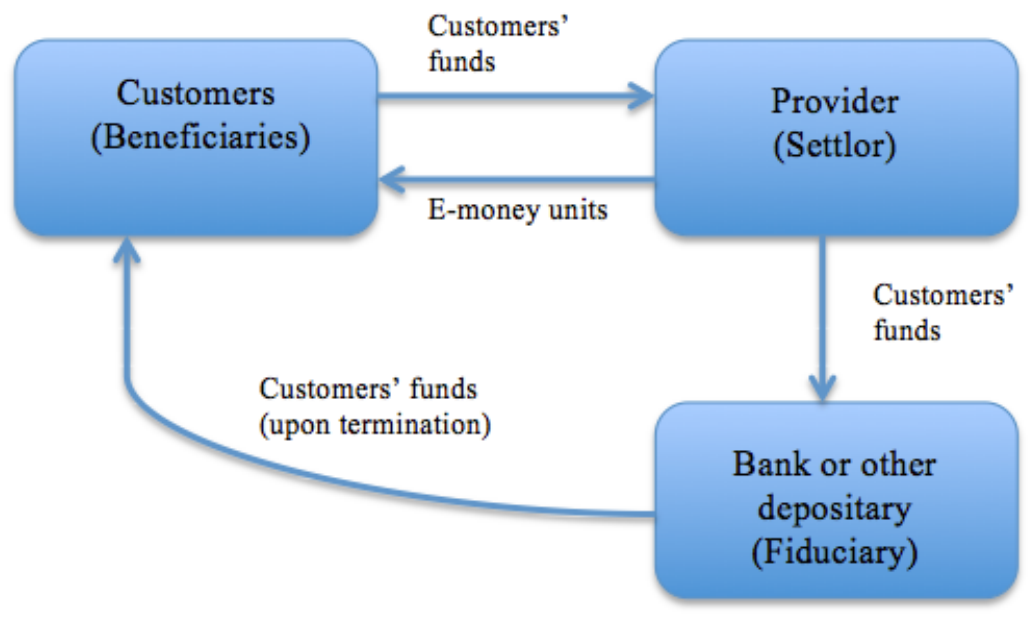

\footnotetext{
${ }^{49}$ The fiduciary contract will specify who these beneficiaries are. In some jurisdictions, the settlor or any third party as specified in the contract may be beneficiaries of the fiducia. See Cámara Lapuente (n 43) 194; Miguel Virgós Soriano, El trust y el derecho español (Thomson/Civitas 2006) para 43. In others, even the fiduciary may be designated as beneficiary. See French Civil code, art 2016. This, however, is prohibited in many Latin American jurisdictions. See art 8.1 of Paraguayan Ley 921/96 de Negocios Fiduciarios (hereinafter, "Paraguayan Fiduciary Contracts Act"); or art 265.4 of Peruvian Ley 26.702, General del Sistema Financiero y del Sistema de Seguros y Orgánica de la Superintendencia de Banca y Seguros (hereinafter, "Peruvian Financial System Act").

${ }^{50}$ In Bolivia, for example, see s 5, art 3 of the Resolución Autoridad de Supervisión del Sistema Financiero (ASFI) $n^{\circ} 835 / 2011$ (hereinafter, "Bolivian Regulation on M-Money Providers"). In Peru, see art 15 of the Resolución de la Superintendencia de Banca y Seguros (SBS) n ${ }^{\circ}$ 6283-2013 that regulates the Reglamento de Operaciones con Dinero Electrónico (hereinafter, "Peruvian Regulation on E-Money Transactions").
} 
In some jurisdictions, customers will transfer the funds to the Provider under a fiduciary contract, which holds the Provider as a fiduciary. ${ }^{51}$ If the Provider does not have the necessary infrastructure to assume safeguarding duties it will normally deposit the customers' assets with a financial institution, which may not have fiduciary duties under the law. This potentially undermines the protection of customers' funds. Graphic 5 depicts this situation.

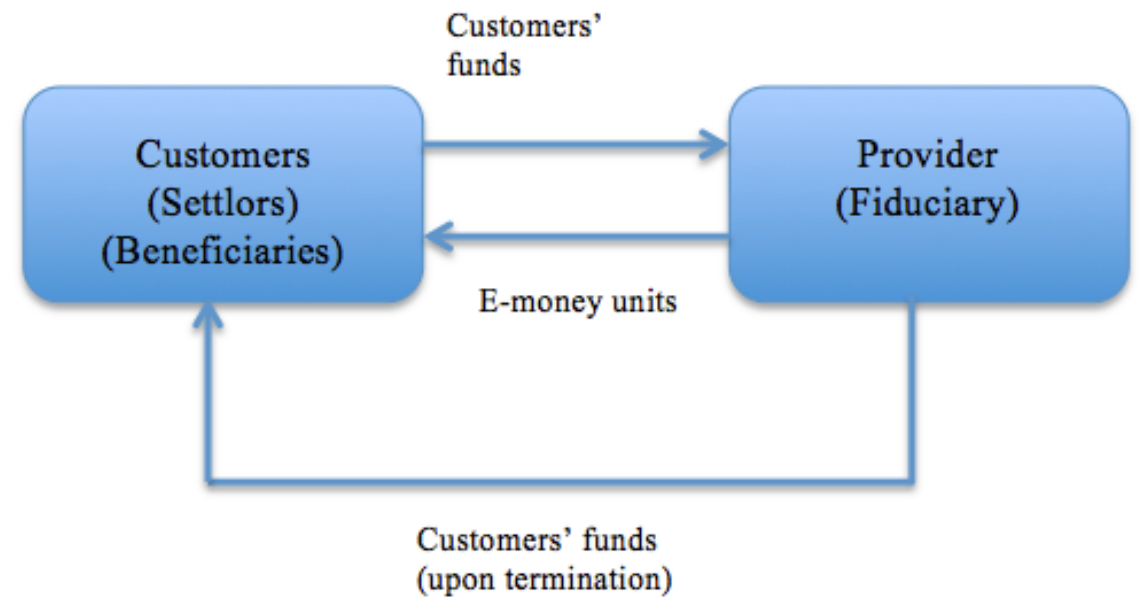

Graphic 5. Fiduciary transactions in the context of e-money (II)

Alternatively, the Provider could be considered the beneficiary, and the bank the fiduciary. In order to protect the customers' interest in the funds the customers and the Provider could enter into a second fiduciary contract, where the Provider would be the fiduciary, and customers the beneficiaries.

\section{Fulfilment of functions}

a) Fund isolation

\footnotetext{
${ }^{51}$ This is less common in Latin American jurisdictions. In Uruguay, see Ley no. 19.210 de Inclusión Financiera (hereinafter, "Uruguayan Financial Inclusion Act"), art 5.
} 
The legal implications of the settlor's transfer of property to the fiduciary are particularly relevant when examining the effects of the fiduciary's insolvency on customers' funds. While some jurisdictions recognize the validity and effects of such transfers, others do not.

There are various ways in which a fiduciary can hold property rights over fiduciary assets. Some jurisdictions conceive fiduciary assets as a patrimony ${ }^{52}$ of the fiduciary, separate from her personal patrimony. In these cases, when the fiduciary is involved in an insolvency proceeding, the fiduciary assets do not form part of the insolvent estate. The fiduciary contract is terminated and the assets are transferred to the beneficiary. ${ }^{53}$ In some cases, legislators have introduced express provisions to guarantee the isolation of those assets. ${ }^{54}$

Some jurisdictions allow creditors of the fiduciary patrimony to have recourse against the settlor's patrimony when the former is insufficient to satisfy all claims. ${ }^{55}$ This issue can be addressed through contractual provisions limiting what creditors of the fiduciary patrimony can claim. ${ }^{56}$ Contractual solutions, however, are far from perfect. ${ }^{57}$

A more innovative approach is that of the fiduciary assets constituting an independent patrimony from those of the settlor, the fiduciary and the beneficiary. In Quebec, for example, 'a fiducie involves the constitution of a patrimony by appropriation (patrimoine d'affectation), that is to say a patrimony dedicated to a purpose, and the [fiduciary] is characterized as an administrator of the property of another person. ${ }^{58}$ The settlor, fiduciary and beneficiary do not have any property rights over the assets. ${ }^{59}$ Consequently, in the event

\footnotetext{
${ }^{52}$ A patrimony can be broadly defined as an autonomous mass with a set of assets answerable for the set of liabilities. See Barrière (n 11) 251.

${ }^{53}$ In France, in the absence of any beneficiaries, the fiduciary assets return to the settlor. See Code Civil Français, arts 2029.2, 2030.

${ }^{54}$ See eg Code Civil Français, art 2024.

${ }^{55}$ See Code Civil Français, art 2025.

${ }^{56}$ See Barrière (n 11) 250-254.

${ }^{57}$ For an account of some of the problems these solutions pose, see ibid. Other solutions have been proposed, but they would not fit the particularities of e-money customers.

${ }^{58}$ Cantin Cumyn (n 44) 7-8.

${ }^{59}$ See Civil Code of Québec, arts 1261, 1265. Unlike in the French fiducie, where the fiduciary has title to the real rights in the property that has been put into the fiducie. See Barrière (n 11) 239. In Peru, the fiduciary patrimony also seems to be an autonomous patrimony from those of the settlor, the fiduciary and the
} 
of the fiduciary's insolvency, the fiduciary contract is not necessarily terminated like in the previous cases. ${ }^{60}$

Some civil law countries accompany the rules stipulating the existence of a separate patrimony with insolvency protections that permit the separation of fiduciary assets upon the fiduciary's insolvency, ${ }^{61}$ whereas others even provide for the replacement of the fiduciary on an interim basis, when insolvency proceedings may jeopardize the performance of its duties. $^{62}$

In the context of e-money services, this analysis poses different questions depending on how the fiduciary contract applies to the e-money transaction. Under the first formula described in Section III.A.1, the Provider (i.e. settlor) enters into a fiduciary contract with a financial institution (i.e. fiduciary) under which the latter manages the customers' funds (i.e. fiduciary assets) for the benefit of the former's customers (i.e. beneficiaries). If property over the funds were transferred to the fiduciary, customers' interests in the fiduciary assets would only be protected against insolvency risk if those assets were separated from the fiduciary's patrimony. If there were no transfer of property under the fiduciary contract, the protection of customers' interests in the fiduciary assets would require the segregation of those assets from the patrimony of the Provider.

Under the second formula, property over the customers' assets would necessarily have to be transferred to the fiduciary for the fiduciary contract to fit the structure of the e-money

\footnotetext{
beneficiaries. See Texto Concordado de la Ley General del Sistema Financiero y del Sistema de Seguros y Orgánica de la Superintendencia de Banca y Seguros (hereinafter, "Ley no 26702 SBS Peru"), art 241. The language, however, is somehow confusing as it refers to "fiduciary ownership" (dominio fiduciario). In Paraguay, despite the legal reference to an "autonomous patrimony" (patrimonio autónomo), the legal nature and effects of the fiduciary patrimony seem closer to those of a separate patrimony of the fiduciary. An important element in this conclusion is the termination of the fiduciary contract upon the liquidation of the fiduciary. See Paraguayan Fiduciary Contracts Act, art 41.6.

${ }^{60}$ See Civil Code of Québec, arts 1296 and 1297. A new fiduciary will be appointed according to the terms provided by the settlor in the contract or as determined by the court. See Civil Code of Québec, art 1277. See also Ley 26702 SBS Peru, art 253.

${ }^{61}$ See eg art 71. VII. E) Mexican Act on Business Insolvency; see also art 2024 French Code civil, or art 155 (1) of the Italian Insolvency Act; Bolivian Commercial Code, art 1410; Paraguayan fiduciary Contracts Act, arts 10, 13; Peruvian Financial System Act, arts 241, 254.

${ }^{62}$ See eg art 2027 French Code civil.
} 
transaction. ${ }^{63}$ Protecting customers' interests in the assets would require segregating the fiduciary assets from the personal patrimony of the Provider. If the Provider were to deposit the assets with a bank, protection of customers' funds would also require segregating the fiduciary assets from the bank's patrimony. However, as mentioned above, this would need to be expressly included in the fiduciary contract between customers and Provider.

\section{b) Fund safeguarding}

Fund safeguarding relates to the personal obligations imposed on the fiduciary by legal institutions in civil law countries. However, some of those personal duties are inextricably linked with the fund isolation function outlined above. In particular, fund isolation can be rendered very difficult if there are no duties and limits on the way the fiduciary stores and manages the customers' funds. Some of the fiduciary laws studied include express provisions requiring fiduciaries to keep fiduciary assets segregated, ${ }^{64}$ while in jurisdictions where there is no express stipulation the duty can be deduced from the autonomy of the fiduciary patrimony, ${ }^{65}$ and the fiduciary's mandate to manage that patrimony to fulfil the terms of the fiduciary contract. ${ }^{66}$

Parties to a fiduciary contract can agree on duties that will bind the fiduciary's use of the fiduciary assets for the projected purpose. ${ }^{67}$ Although such fiduciary duties could also be determined by law, most statutes generally refer to the duty of the fiduciary to serve the terms of the fiduciary contract, or its duty to act with necessary diligence. ${ }^{68}$ When fiduciary duties

\footnotetext{
${ }^{63}$ In an e-money transaction customers purchase e-money units issued by the Provider, who gains a proprietary right over the money used to pay for those units. See Section II.A.

${ }^{64}$ See eg art 386 of Mexico's General Act on Credit Transactions; arts 2447sexies and 2447septies of the Italian Codice civile; art 1259 Quebec Civil code.

${ }^{65}$ See eg Paraguayan Fiduciary Contracts Act, art 10 and 13; Uruguayan Fideicomiso Act, art 6.

${ }^{66}$ See eg French Code civil, arts 2021, 2022; Luxembourg Fiduciary Contracts Act, arts 6, 7.

${ }^{67}$ See eg Uruguayan Fideicomiso Act, art 4.3; French Code civil, arts 2018.6 ${ }^{\circ}, 2022$, 2026; Luxembourg Fiduciary Contracts Act, art 7(3).

${ }^{68}$ See eg French Code civil, arts 2018.6², 2022, 2026; Mexico's General Act on Credit Transactions, art 391. One exception is Argentina: see eg Argentinian Act $\mathrm{n}^{\circ}$ 24.441, arts 4.d), 6 and 7. One imaginative solution is that of Luxembourg, where the fiducie is primarily defined on proprietary terms, but a reference is made to the
} 
are not expressly included in the law, courts may find certain duties implicit in the adequate safeguarding of assets - but only if the transaction is conceived as one where the fiduciary acts in the beneficiary's interest, as opposed to simply holding different interests in a patrimony.

Under a common law trust, beneficiaries have an equitable right in the trust assets that allows them to trace the proceeds resulting from the assets transferred in an unauthorized disposition in breach of fiduciary duties. ${ }^{69}$ The status of beneficiaries' claims in such cases is more problematic, as the law of subrogation in rem, which fulfils a similar function to tracing, is nonetheless less developed. ${ }^{70}$ When the assets are money in bank accounts, however, the protection may be similarly weak. ${ }^{71}$

Beneficiaries under fiduciary contracts have other rights available to protect their interests. Typically they have a right to information about the fiduciary's use of the fiduciary assets $^{72}$ and a right to substitute the fiduciary under certain circumstances. ${ }^{73}$ Some jurisdictions specifically provide that the settlor and the beneficiaries may take action against the fiduciary to compel him to perform his obligations, to refrain from any harmful action to the fiduciary patrimony or the beneficiaries' rights, and to impugn any fraudulent acts. ${ }^{74}$ In other jurisdictions, however, beneficiaries have very limited rights to protect the fiduciary assets. $^{75}$

Fiduciary contracts could provide for specific rules to ensure that the Provider always has a 1:1 ratio between the total outstanding amount of e-money issued (or "e-float") and the

\footnotetext{
law of mandate contract to fill the gaps in the duties of the fiduciary. See Luxembourg Fiduciary Contracts Act, $\operatorname{art} 7$ (1).

${ }^{69}$ See Thomas and Hudson (n 27) 33.01-33.120. For tracing in general, see Gullifer, Goode on Legal Problems of Credit and security ( $4^{\text {th }}$ edn) $1-57,41$.

${ }^{70}$ Martín Padilla, 'La formación del concepto de subrogación real' (1975) 1111; Roca Sastre 'La Subrogación real' (1949) 281; Vallet de Goytisolo, 'Pignus tabernae' (1953) 483.

${ }^{71}$ Westdeutsche Landesbank v Islington [1996] AC (Lord Browne-Wilkinson).

${ }^{72}$ See eg Argentinian Act $n^{\circ} 24.441$, art 7.

${ }^{73}$ See eg Luxembourg Fiduciary Contracts Act, art 7(6).

${ }^{74}$ See Civil Code of Québec, art 1290.

${ }^{75}$ See Figueroa (n 11) 725-726.
} 
customers' funds backing it. There are three main categories of rules that could serve this purpose: a) the parties could expressly restrict the Provider's right to use customers' funds, ${ }^{76}$ b) the Provider could be required to manage customers' funds within very narrow parameters, eg investing the cash in highly liquid assets such as bank deposits or highly rated government securities $;{ }^{77}$ and c) the parties could agree that the Provider will diversify the assets in which it will invest the customers' funds.

These rules can form part of the fiduciary duties included in the relevant fiduciary contract, determining how the fiduciary will manage or dispose of the assets to fulfil the purpose agreed in the contract. These duties can be expressed explicitly in the fiduciary contract, in specific e-money regulation, in fiduciary legislation or in general law. They can also be implied by the courts to "fill a gap" in the fiduciary contract, particularly in those jurisdictions where the fiduciary contract has been recognized and developed by case law.

\section{c) Protecting customers' interests against operational risks}

The fiduciary duties under a fiduciary contract can also serve as a protective mechanism against the operational risks described in Section II.B. Fiduciary contracts can provide for two mechanisms to reduce operational risk with regards to e-money customers' funds.

First, the fiduciary may be required to keep records of the accounts where it keeps the fiduciary assets and to have those accounts audited by an authorized auditor. ${ }^{78}$ These

\footnotetext{
${ }^{76}$ Some jurisdictions mandate that a fideicomiso is settled for 100 per cent of e-money issued and in circulation. See eg, Paraguayan E-Payments Regulation, art 15. Brazil represents an interesting case because it requires the Provider to guarantee the e-money issued following a progressive scale with a 20 per cent yearly increase of the total proportion of e-money guaranteed from 2016 to 2019. By 2019, Providers must guarantee that 100 per cent of the e-money issued is guaranteed. See Circular no. 3681 de 4 de Novembro de 2013 do Banco Central do Brasil, art 12.9. In other jurisdictions, the intermediation of e-money customers' funds deposited in bank accounts is expressly prohibited. See eg Uruguayan Financial Inclusion Act, art 6.

${ }^{77}$ It is very common among Latin American regulators to restrict the securities in which e-money customers' funds can be invested to securities issued by the federal government or central bank. See eg, Reglamento de Fideicomiso contenido en la Recopilación de Normas para Bancos y Entidades Financieras (RNBEF), Chapter XVII (hereinafter, "Bolivian Regulation on Fideicomiso"), art 12; Circular BC Brasil, no. 3681, art 12.1.II; Peruvian Regulation on E-Money Transactions, art 16.

${ }^{78}$ Auditing can help ensure the integrity of the system. See Klein and Mayer (n 21) 13.
} 
requirements may be expressly included in the fiduciary contract or may be provided by law. The fiduciary contract could even designate a specific auditor or describe the process of designation.

Second, the parties may provide for a third party expert to monitor the fulfilment of the fiduciary's duties, especially those relating to fund safeguarding and auditing. Normally, parties will specify in the terms of their agreement whether the settlor or beneficiary can delegate their supervisory powers over compliance of fiduciary duties to a third party ("the Protector"). ${ }^{79}$ However, some jurisdictions expressly provide that the settlor and any beneficiaries have the ability to do so. ${ }^{80}$

Additionally, the fiduciary has a duty to account to the settlor and/or beneficiary for the management of the fiduciary assets. ${ }^{81}$ The parties could agree that such duty to account is to be subject to the review of a third party expert. ${ }^{82}$ However, this would seemingly provide less protection against the mismanagement of customers' funds by the Provider because the third party expert would focus only on the accuracy of the information provided by the Provider, not on the Provider's compliance with its fiduciary duties. Nevertheless, allowing a Protector to intervene in the supervision of the Provider's compliance with its fiduciary duties is important as e-money customers in developing countries are likely to have very low levels of financial literacy. ${ }^{83}$ This could prevent them from monitoring the Provider effectively and leave room for the latter to act opportunistically and to jeopardize the safety of customers' funds.

\footnotetext{
${ }^{79}$ If the delegation of supervisory powers were to be challenged, a court could find that some default rules also allow the settlor to delegate those powers. See section III.B.

${ }^{80}$ For example, the Civil Code of Québec allows the settlor or beneficiary to delegate their monitoring powers. See Civil Code of Québec, arts 1287 et seq. Art 2017 of the French Civil Code gives the settlor similar powers but not the beneficiaries.

${ }^{81}$ See eg Paraguayan Fideicomiso Act, art 25.13.

${ }^{82}$ In Brazil, for example, see Circular no. 3682 de 4 de Novembro de 2013 do Banco Central do Brasil (hereinafter, "Circular BC Brasil no. 3682"), art 22.

${ }^{83}$ See Organisation for Economic Cooperation and Development, 'PISA 2012 Results: Students and Money: Financial Literacy Skills for the 21 st Century (Volume VI)' (2014) <http://www.oecd.org/pisa/keyfindings/pisa2012-results-volume-vi.htm>.
} 
Protectors would need a solid financial and/or technological background and a deep understanding of the financial services and mobile industries in the relevant jurisdiction. The role could be done by public institutions such as e-money regulators, or alternatively by central banks and securities regulators. ${ }^{84}$ It could equally be performed by private institutions such as auditors, banks, law firms or technology consultants.

Where a private entity undertakes the role of Protector, there is a concern that the third party expert may act in its own interest rather than in the interest of e-money customers. It is therefore useful to query whether the role implies the assumption of fiduciary duties by the third party expert towards e-money customers. The parties could so agree under respective agreements. Mandatory rules could also specify the application of fiduciary duties to protect the interests of e-money customers. In the absence of any such agreement or of any mandatory rules, the question would be answered on a case-by-case basis. While courts are likely to resort to default rules to fill any gaps in the parties' agreement, it may be difficult to effectively appoint a protector if the law is scant on the duty to account and fiduciary duties.

\section{B. Contractual/obligational Alternatives: The Mandate Contract}

Under a mandate contract, one party (the agent) commits to act on behalf of another (the principal) for a fee, unless otherwise specified. ${ }^{85}$ The agent is liable to fulfil the mission mandated by the principal in the capacity and under the circumstances specified in the contract. The mandate contract provides a basic foundation for other, more complex, legal mechanisms such as deposit and loan contracts, as well as fiduciary mechanisms.

In the context of e-money services, the mandate contract cannot be used as the sole institution to regulate the relationship between the customer and the Provider. By purchasing

\footnotetext{
${ }^{84}$ This seems to be the most common situation in Latin American jurisdictions. For example, in Peru, the Banking and Insurance supervisor is in charge of monitoring authorized e-money issuers. See Peruvian EMoney Act, art 6.3. In Paraguay, the Central Bank undertakes those supervisory functions. See Paraguayan EPayments Regulation, art 20.

${ }^{85}$ See eg French Civil Code, art 1984 et seq.
} 
e-money from the Provider, the customer relinquishes proprietary rights over the funds in exchange for the right to dispose of the e-money. The customer would thus not have the legal capacity to mandate the Provider to dispose of funds that she no longer owns.

Nevertheless, the mandate contract could regulate the relationship between the Provider and a bank. The Provider could mandate the bank to keep custody of the customers' funds in accordance with a series of duties specified in the contract. Like the fiduciary under the fiduciary contract, the agent would be bound by the duties specified by the parties in the contract or the enhanced good faith duties provided by law. Such quasi-fiduciary responsibility vis-à-vis the principal could potentially provide e-money customers protection against liquidity and operational risk. The mandate contract, however, would not provide protection against the risk of the Provider or the bank becoming insolvent. The segregation of those assets would require an express legal mandate or the creation of a separate patrimony from that of the Provider or the bank. These are, precisely, the characteristics of the fiduciary contract. If the agent became insolvent, the assets would not fall into the agent's insolvent estate because they never left the principal's patrimony. ${ }^{86}$

The mandate contract cannot, per se, effectively protect e-money customers against the risk of the Provider's insolvency. However, as a legal mechanism de minimis, mandate contracts provide an important body of default rules that regulate the duties of the Provider towards the customer, arising from the statutory duties of an agent to act in the interest of the principal, ${ }^{87}$ and to exercise due care and skill. ${ }^{88}$

Under certain circumstances, fiduciary contracts can effectively isolate customers' funds in the event of the Provider's insolvency, as well as provide customers with protection against insolvency risks, protection against certain operational risks, and the flexibility to introduce extra duties. Their main handicap is their lack of general background rules

\footnotetext{
${ }^{86}$ A replevin action (acción reivindicatoria) will be available to the principal. See Sánchez Aristi (n 43 ) 252.

${ }^{87}$ See eg Spanish Commercial code, art 225; Spanish Supreme Court decision of 5 February 1964.

${ }^{88}$ See eg German Civil code, s 276.
} 
regulating the duties of the fiduciary towards the customer. This is the gap that other private law arrangements, such as the mandate contract, are able to fill. Interestingly, some countries that have defined fiduciary transactions by focusing on the relationship of the parties with each other rather than on the assets have done so by using the mandate and commission contracts as a model. ${ }^{89}$ This approach could be the blueprint for mobile e-money transactions.

To hold that the mandate's shortcomings can be corrected by means of better contractual clauses would be wrong for two reasons. First, a contract cannot pre-determine the protection of a right upon insolvency unless the right created by the contract belongs to one of the categories that enjoy insolvency protection. ${ }^{90}$ Second, courts confronted with a difficult case of fund isolation (eg upon the Provider's or the bank's insolvency) would lack background principles with which to determine whether customers' funds have been properly ring-fenced. ${ }^{91}$ Consequently, a mandate contract would not be suitable on its own to regulate e-money services, ${ }^{92}$ at best, it could provide the basis for the Provider's duties vis-à-vis its customers, but not for the rights over the funds.

\section{Regulatory Alternatives: Regulating Functional Duties Directly and/or Requiring}

\section{Insurance}

The mechanisms and their respective drawbacks described above reveal the difficulty of providing a single solution for the effective protection of e-money customers' funds in civil law jurisdictions. In light of this difficulty, policy makers have two alternatives. First, the

\footnotetext{
${ }^{89}$ Eg in Paraguay, the Paraguayan Fiduciary Contracts Act distinguishes between those fiduciary contracts under which property is transferred to the fiduciary and those under which property remains with the settlor. The latter are referred to as encargo fiduciario or "fiduciary mandate".

${ }^{90}$ See Section II.C.

${ }^{91}$ In the Lehman Brothers' saga, English courts had to make a similar decision on whether customers' funds should be protected. The outcome was for a period uncertain despite the legal institution used to protect customers' money being a trust. See In the matter of Lehman Brothers International (Europe) (In Administration), [2012] UKSC 6; on appeal from: [2010] EWCA Civ 917. The first case to be decided was In re Lehman Brothers International (Europe) [2009] EWHC 3228 (Ch). If the legal institution used was a mandate, which has no explicit bankruptcy protection rules, the outcome would have been even more uncertain.

${ }^{92}$ For a distinction between mandate contracts and trusts, see Figueroa (n 11) 735.
} 
functions outlined above could be regulated directly, eg under an e-money statute or regulation. Second, in the absence of such direct regulation, regulation could protect customers' funds indirectly by, for instance, requiring insurance.

\section{Direct regulation of functional duties}

The first solution would be to introduce a specific piece of legislation requiring Providers to adopt some of the protective mechanisms described in Section III.B, eg fund isolation, fund safeguarding and protection against certain operational risks. Direct regulation could also grant e-money customers the right to monitor the Provider's compliance with these duties, or require the appointment of a Protector to do so. ${ }^{93}$ In the European Union, Directive 2009/110/EC of 16 September 2009 (the "E-Money Directive") is an interesting example of direct regulation in this regard. ${ }^{94}$ The 2007/64/EC Payment Services Directive also provides for specific safeguarding requirements (in case the Provider undertakes other activities), with a specific mandate to avoid commingling of funds, and protection against the Provider's other creditors in the event of insolvency, but without specifying in advance the property arrangements through which this must be achieved. ${ }^{95}$

An explicit regulatory solution looks to be the best option as specific rules can be promulgated to afford the specific protections, and allocation of rights and obligations, required. The challenge, however, is that the specific legal rules also need to be flexible

\footnotetext{
${ }^{93}$ The same considerations made regarding the possibility of customers delegating their supervisory powers over the fiduciary's duties upon a third party expert would also apply here. See Section III.A.

${ }^{94}$ In the EU, the Directive 2015/2366/EU, of 25 November 2015 (hereafter the "Payment Services Directive II", or PSD II) adopts such functional approach by imposing upon payment systems (1) safeguard measures (art 10 (1)); and (2) conduct duties of the payment services provider (arts 38 et seq). The Directive 2009/110/EC of 16 September 2009 (the "E-Money Directive") requires similar safeguarding mechanisms. For duties applicable to e-money issuers see arts 10 to 13 of the E-Money Directive. The division of competences between the EU and the Member States has helped the EU develop a functional approach, which can be a useful blueprint for countries struggling with how to properly implement the different functions in their civil law codes. It is important to note, however, that under EU law, Directives set goals that all Member States need to achieve. Member States will decide how best to achieve those goals by implementing EU Directives into their legal systems. As a result, although they will all aim at the same objective, Member States might resort to different legal mechanisms and different regulatory instruments in their pursuit. For an analysis of the transposition status of the E-Money Directive in each of the EU Member States, see http://ec.europa.eu/finance/payments/emoney/transposition/index en.htm\#maincontentSec2 (updated as of May 2012).

${ }^{95}$ See arts 10 (1)(a) and (b) PSD II.
} 
enough to accommodate new situations as the market evolves and new problems arise. Such flexibility depends on whether the rules can be subject to the kind of interpretation exercise described in Section II.C, as well as on how they interact with other rules. Furthermore, if the duties are regulated in functional terms, this implies that the parties and the courts will still be left with the question of what is the private law arrangement that supports the regulatorily imposed duties. It is difficult to consider a regulatory approach as the sole solution, but, as we argue below, the regulatory approach will most likely form a key part of the solution to protecting e-money customers.

\section{Insurance}

Regulators could also require the insurance of e-money customers' funds against any of the risks identified in Section II.B. This is an approach also adopted in the European Union for payment services. $^{96}$

The requirement to insure customers' funds could be legislated to strengthen the protection that existing legal instruments would provide to customers' funds, or to protect customers' funds where no legal instrument in the relevant jurisdiction fulfils the functions identified in section III.A. Regulators would have to decide whether insurance would be provided by the market or by public institutions.

Although an insurance policy, either as a complementary or a standalone mechanism, would ensure effective protection to e-money customers' funds, there are important issues to consider.

First, the e-money market conditions may not be ideal for the viability of an insurance scheme, eg where the number of potential e-money customers is small. ${ }^{97}$

\footnotetext{
${ }^{96}$ See Payment Services Directive II, art 10.1(b); E-Money Directive, art 7.1.

${ }^{97}$ Insurance companies require large numbers of clients in order to avoid the risk of facing numerous simultaneous payouts that would deplete its resources in a short period of time.
} 
Second, one could expect Providers to pass on the cost of mandatory insurance to customers. This could have a serious impact on the demand for e-money services and on its potential as a tool for financial inclusion. One should expect the cost of insurance covering all the risks described in section II.B to be higher than insurance used as a complementary mechanism to compensate for specific deficiencies.

Third, in the event of the Provider's insolvency, insurers may refuse to compensate customers until the end of the insolvency proceedings, which may impose hardship on impecunious e-money customers. Additionally, given the lack of sophistication of many emoney customers it will be important to ensure easy access to financial compensation.

Fourth, insurance may create moral hazard, as Providers would have fewer incentives to comply with the protection rules described above. Effective monitoring by the competent authorities, as described in section II, will be essential. ${ }^{98}$

Fifth, insurance will only give customers a personal claim for damages against the insurance company in the event of the Provider's insolvency. This protection is not legally as strong as that provided by other mechanisms where customers remain the owners of their funds or where those funds, despite being owned by the Provider, are separated from its personal patrimony. ${ }^{99}$

Finally, insurance will not eliminate counterparty credit risk for e-money customers. Insurance, effectively, will substitute the risk of the Provider becoming insolvent with the risk of the insurer becoming insolvent. Any insurance scheme should rely on financially robust insurance companies or ensure sufficient public funds to cover the potential losses of customers. Where the insurance industry is not very strong or where the government may be in a situation of financial hardship, access to compensation must be made available through other means.

\footnotetext{
${ }^{98}$ Given the financial pressure borne by guaranteeing e-money customers' funds, one could expect these companies and public entities to have a strong incentive to monitor the Provider of mobile services.

${ }^{99}$ See Section III.A.
} 
Table 2 provides a summary of our findings in relation to the different legal mechanisms available to regulators in civil law countries to protect e-money customers' funds.

\begin{tabular}{|c|c|c|c|c|}
\hline Function & Specification & Fiduciary provisions & Mandate & $\begin{array}{c}\text { Regulatory } \\
\text { solutions }\end{array}$ \\
\hline \multirow[t]{3}{*}{ Fund isolation } & $\begin{array}{l}\text { Segregation from the } \\
\text { Provider's funds. }\end{array}$ & $\begin{array}{l}\text { If customers are } \\
\text { beneficiaries, funds are } \\
\text { protected. }\end{array}$ & $\begin{array}{l}\text { No explicit } \\
\text { statutory } \\
\text { provisions. }\end{array}$ & $\begin{array}{l}\text { Depends on } \\
\text { coordination } \\
\text { with } \\
\text { insolvency } \\
\text { rules. }\end{array}$ \\
\hline & $\begin{array}{l}\text { Segregation from the } \\
\text { depositary institution's } \\
\text { funds. }\end{array}$ & $\begin{array}{l}\text { Depends on whether the } \\
\text { Provider accounts are } \\
\text { fiduciary accounts. }\end{array}$ & As above. & As above. \\
\hline & $\begin{array}{l}\text { Segregation from other } \\
\text { customers' funds. }\end{array}$ & $\begin{array}{l}\text { Depends on the terms of } \\
\text { the fiduciary structure: if } \\
\text { each fiduciary } \\
\text { arrangement is } \\
\text { contemplated as a } \\
\text { separate transaction } \\
\text { where the customer is the } \\
\text { beneficiary, funds are } \\
\text { protected. }\end{array}$ & As above. & As above. \\
\hline $\begin{array}{l}\text { Fund } \\
\text { safeguarding }\end{array}$ & Liquidity. & $\begin{array}{l}\text { Explicit duties included } \\
\text { in the fiduciary } \\
\text { agreement, backed by } \\
\text { duties implied by law } \\
\text { (the extent of such } \\
\text { implied duties varies } \\
\text { across jurisdictions). }\end{array}$ & $\begin{array}{l}\text { Explicit duties } \\
\text { included in the } \\
\text { fiduciary } \\
\text { agreement, } \\
\text { backed by } \\
\text { enhanced good } \\
\text { faith duties } \\
\text { implied by law } \\
\text { (vary less } \\
\text { across } \\
\text { jurisdictions). }\end{array}$ & $\begin{array}{l}\text { Yes (depends } \\
\text { on nature of } \\
\text { regulated } \\
\text { entity). }\end{array}$ \\
\hline $\begin{array}{l}\text { Protection of } \\
\text { customers' } \\
\text { interests }\end{array}$ & Fiduciary duties. & As above. & As above & Yes. \\
\hline
\end{tabular}

Table 2. The protection of e-money customers' funds under civil law 
The table shows there is no single mechanism that will effectively protect e-money customers against the three risks identified in Section II.B; so we anticipate any regulatory strategy to include a combination of different legal mechanisms. In this context, the interaction of the rules applicable to such mechanisms will be crucial to provide effective protection. We turn to all these questions now.

\section{A ROADMAP OF LEGAL STRATEGIES FOR E-MONEY}

The previous sections discussed the benefits and risks of using different approaches as a background for e-money systems. None of the private law alternatives (fiduciary or mandate contracts) adequately fulfils all the necessary functions, which would make a specific regulatory intervention preferable. We now use the previous analysis to provide a broader menu of policy choices. First, we begin by exploring the options available to regulators to protect e-money customers' funds (A). Second, we introduce additional arguments about how regulatory certainty should be weighed against the need to foster competition between emoney models and the legal compatibility of rules, both on a domestic and a cross-border basis (B). Finally, we address issues of regulatory capacity and financial literacy that, in practice, limit regulatory intervention $(\mathrm{C})$.

\section{A. A Summary of the Options Available to Regulators}

\section{Fund Isolation}

The first priority for policy-makers should be to guarantee the isolation of customers' funds. Policy strategies will vary depending on whether fiduciary contracts are recognized in the relevant jurisdiction and on the treatment given to fiduciary assets receiving such recognition.

Where fiduciary contracts are recognized in the relevant jurisdiction and fiduciary assets are separated from the personal patrimony of the fiduciary, Providers should rely on 
fiduciary contracts to protect customers' funds. Lawmakers could include statutory requirements for those Providers to hold customers assets under a fiduciary contract (or including it as a preferred model to safeguard customers' funds). Several civil law jurisdictions have implemented this regulatory strategy, often within the broader framework of e-money regulation. ${ }^{100}$

In jurisdictions where fiduciary contracts are recognized but the separation of assets from the fiduciary's personal patrimony is unclear, it will be important for regulators to clarify customers' protection against the risk of the fiduciary's insolvency. Direct regulation could be of general reach (for all fiduciary contracts) or narrower in scope (eg only affecting fiduciary contracts for e-money accounts). Alternatively, in countries where private law arrangements are difficult to amend without upsetting the whole civil code system this could be done by introducing specific provisions in the relevant insolvency laws, which would give e-money customers a right to segregate their assets from those of the insolvent estate. ${ }^{101}$ Yet another possibility would be to introduce ring-fencing requirements to require Providers, for example, to carry on their e-money business through a separate legal entity, which would hold the latter's funds under a fiduciary contract. ${ }^{102}$ Regulators could also require Providers to subscribe to an insurance policy to cover the risks for customers' funds. This alternative could be complementary to the fund isolation strategies outlined above, or be enacted as a standalone option.

Where fiduciary contracts are not recognized, there are limitations on the necessary protective mechanisms private parties can create to make e-money work. In such a context,

\footnotetext{
${ }^{100}$ See eg Peruvian E-Money Act, art 6.1.

101 This particular approach is likely to negatively impact ordinary creditors of the Provider. Accounting principles should be adapted so that the Provider's financial accounts reflect a true picture of its solvency.

${ }^{102}$ Instead of isolating funds via a specific property right the law would require Providers to create such separate patrimony through a different entity. This is a common approach in many Latin American jurisdictions, where e-money issuers are required to provide e-money services through a separate institution. The Provider will also need to ensure that each entity carries its own accounting books. See eg Reglamento de Fideicomiso contenido en la Recopilación de Normas para Bancos y Entidades Financieras (RNBEF), Chapter XVII, art 7; in Brazil, Circulares BC Brasil n³682 y 3683; in Peru, Resolución SBS nº 6286-2013.
} 
legislation could be passed that expressly contemplates e-money as a new type of admissible private law arrangement, without making a broader statement about the admissibility of fiduciary transactions as a whole. ${ }^{103}$ Such legislation could also rely on the enhanced good faith duties of mandate, but should introduce specific fund isolation protection in case of insolvency.

However, there may be reasons why the protection of e-money customers' funds may not justify a full reform of the relevant legal system. ${ }^{104}$ In such cases, those countries cannot entirely rely on an institution like the mandate, because it presumes, rather than regulates, the separation of funds between principal and agent. The patrimonial relation would normally be seen as a loan or a deposit. This would create some friction, due to the lack of background rules on segregation of assets by the borrower (Provider) under the loan, and the lack of background rules that authorize the depositary (Provider) to dispose of the assets under the deposit.

The following table provides a summary of the options available to legislatures for the protection of customers' funds against the risk of the fiduciary becoming insolvent:

\begin{tabular}{|l|l|}
\hline Jurisdictions... & Regulatory options \\
\hline $\begin{array}{l}\text {... where fiduciary } \\
\text { contracts are } \\
\text { recognized }\end{array}$ & $\begin{array}{l}\text { Option 1: where the fiduciary assets are separated from the fiduciary's } \\
\text { personal patrimony, to require Providers to hold e-money customers' funds } \\
\text { under a fiduciary contract by law. }\end{array}$ \\
\cline { 2 - 2 } & $\begin{array}{l}\text { Option 2a: where the fiduciary assets are not separated from the fiduciary's } \\
\text { personal patrimony, to introduce specific modifications in the regime of } \\
\text { fiduciary contracts to separate the fiduciary assets from the fiduciary's } \\
\text { personal patrimony. }\end{array}$ \\
\cline { 2 - 2 } & $\begin{array}{l}\text { Option 2b: where the fiduciary assets are not separated from the fiduciary's } \\
\text { personal patrimony, to introduce specific modifications to the relevant } \\
\text { bankruptcy law to ring-fence the assets in the event of the Provider's } \\
\text { insolvency. }\end{array}$ \\
\hline
\end{tabular}

\footnotetext{
${ }^{103}$ In some countries the regulation of certain financial services, including e-money, has fostered the development of fiduciary contracts. See de Waal (n 12); Figueroa (n 11); Lupoi (n 10) 275, 285, 291.

104 These reasons include, among other, political reasons, incompatibility within the country's legal tradition or the broader legal system, implications in other areas beyond mobile money services for which the relevant jurisdiction may not be ready. Additionally, such a deep reform may take a long time to pass and regulators may feel the urgent need to protect e-money customers' funds.
} 


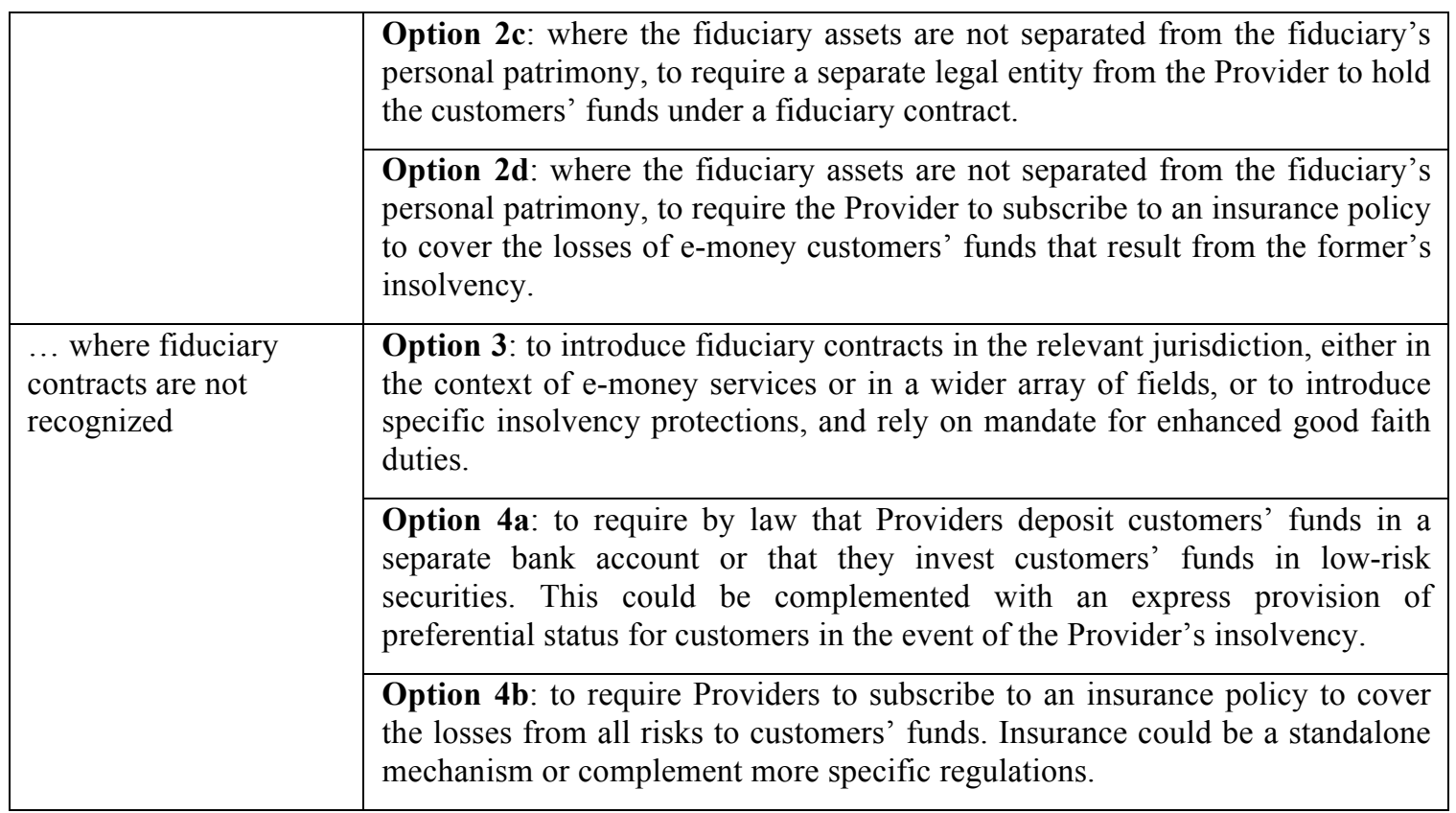

Table 3. A summary of policy options to achieve fund isolation

\section{Fund safeguarding and protection of customers' interests}

The second policy priority is to ensure fund safeguarding and to protect customers from operational risk. Some rules on fiduciary transactions provide broad conduct duties, but many do not. ${ }^{105}$ Even if such duties could be seen as implicit background duties, they may not foster market confidence if their content is too broad and they are able to be derogated from by contract. Specific statutory rules could provide the minimum content of the relationship between Provider and customer necessary to protect the latter's funds. Such content would not be subject to derogation or waiver in the contract. ${ }^{106}$

Such minimum content could include specific safekeeping duties for Providers eg to deposit customers' funds in a separate bank account or to invest customers' funds in safe, low-risk securities, such as government bonds, in the name of the customers. ${ }^{107}$ Regulatory

\footnotetext{
${ }^{105}$ See section III.A.

${ }^{106}$ In Paraguay, for example, Article 25 of the Paraguayan Fideicomiso Act expressly enumerates a series of obligations of the fiduciary that she cannot delegate.

${ }^{107}$ In the EU, the E-Money Directive has adopted this approach due to the absence of an EU regulatory framework for fiduciary contracts that would guarantee a more or less homogenous regulation of fiduciary contracts in all EU Member States. See EU E-Money Directive, art 7.1.
} 
provisions could also specify further the content of safekeeping duties, ${ }^{108}$ and be connected with insolvency rules that provide protection upon the Provider's insolvency (eg rights of separation or priority rights). Such sets of duties would also support fund isolation, and would be of particular importance in countries that do not recognize fiduciary transactions.

Again, another regulatory alternative would be to require Providers to subscribe to an insurance policy that covers the losses of customers' funds in the event that the Provider becomes illiquid or it is not able to return the customers' funds for any reason other than insolvency. This alternative could be complementary to the regulatory strategies outlined in the previous paragraphs or it could be enacted as a standalone option.

In Section III we considered private law and regulatory solutions as alternatives to achieve the same end: one would be driven by the choices of market participants, the other by legislative mandate or regulatory design. However useful that division may have been for illustrating the different choices, in reality it would be rare for a country to adopt an "emoney legislative strategy" that is not a "mixed" strategy, in the sense that it combines (a) reliance on the parties' ability to craft a menu of contractual solutions for market needs, with (b) specific regulatory rules that are tailor-made for the needs of the e-money industry, and (c) private law rules that provide the background for both contract solutions and regulatory rules.

The previous discussion holds important lessons for policy-makers as well as for private parties. Rather than an exercise where we seek the best institution to fulfil the necessary functions the answer may lie in a combination of institutions. Fiduciary transactions are the best private law solution in terms of fund isolation, and in countries that recognize them they should provide the basis for e-money relationships. However, fiduciary transactions provide limited comfort in relation to liquidity and operational risks given the

\footnotetext{
${ }^{108}$ Eg the type of bank where customers' funds can be deposited and whether each customer's funds would be separated from other customer's funds, among others.
} 
lack of specificity beyond the most basic fiduciary duties. Mandate contracts, on the other hand, which say nothing about segregation, provide a more sound and flexible basis for operational duties. Thus, the ideal solution should involve some combination of mandate and fiduciary transactions. Legislation could make a reference to the mandate to fill the possible gaps of the fiduciary's duties in a fiduciary transaction. For private parties this could involve different permutations, which could also give grounds for the Providers to compete between themselves. ${ }^{109}$ In any event, requiring the Provider to subscribe to an insurance policy could always be contemplated as a complementary fall-back option.

\section{B. How Can Legislatures Grant Protection while Fostering Competition between Different E-money Models and Ensuring Cross-border Compatibility?}

If the main problem of private law background rules is their lack of certainty (as they are designed for a wide variety of cases) the problem of regulatory rules is their lack of flexibility. Thus, it is important for policy-makers to consider the trade-offs between certainty and rigidity, an analysis that is particularly useful when comparing regulatory solutions with private law solutions, but which can also be applied to evaluating the different private law solutions.

Let us begin with regulatory solutions. Regulatory rules are typically mandatory, and their scope of application is normally accompanied by a "reserve of activity" clause, meaning that the provisions under the specific act will be applicable only to the entities expressly authorized to provide the regulated service. ${ }^{110}$

\footnotetext{
${ }^{109}$ Two of the multiple options available would be (1) to have a "framework" contract subject to the laws of mandate, followed by a fiduciary contract that regulates the transfer and segregation of funds, or (2) a single contract subject to the laws of fiduciary transactions that operates as the broader contract, and which includes specific operational and conduct duties by the Provider, where a specific reference is made to the laws of mandate.

${ }^{110}$ See arts 5-9, 11, 13, 16, or 18 of the PSD II, and art 10 of the E-Money Directive.
} 
This requires active engagement by the financial supervisor, which must be up to the task. This is particularly important considering that, in many cases, the zeal by which supervisors control compliance ex ante (i.e. before granting the authorization) is greater than that exercised when controlling compliance ex post (i.e. fulfilment of segregation, safeguarding and management duties).

If the supervisor appointed is the central bank, or a similar banking supervisor, the system is most likely to be bank-biased. In particular, the procedures for authorization will tend to mirror the characteristics required for the authorization of financial institutions, which will enjoy an advantage in terms of experience with compliance procedures, and, in many cases, access to the supervisor.

Even assuming that the supervisor runs the ex ante authorization without any bias, it is unclear how it would apply conduct rules ex post. Regulatory rules are considered public law rules for enforcement purposes. This means that, unlike private law rules, their breach entails public enforcement action, which curtails the possibility of constructing rules that regulate the parties' duties flexibly, or imply duties not expressly contemplated in the law.

In addition to enforcement action by supervisors there is also the possibility that the rules are interpreted by civil courts. However, the more specific and self-contained the regulatory rules are, the more difficult it will be for the judge to draw an analogy with the broader laws of "fiduciary transactions" or "mandate contracts". Regulatory rules provide a more certain answer to the contingencies envisaged in those rules, but may leave great uncertainty in the face of unforeseen contingencies.

Furthermore, some rules may actually require classification of the relationship pursuant to private law rules. Insolvency rules, which are the flip side of segregation rules under property rights, normally require that the right of the parties (in this case, the customers) belongs to one of the categories of property/security rights, or, generically, in rem 
rights to dispense enhanced protection upon the insolvency of the Provider. Absent a smooth connection between regulatory rules and private law rules the insolvency court may well conclude that, although the parties' arrangement was regulated by financial provisions, it did not fulfil the requirements under private law to be granted segregation protection. ${ }^{111}$

A country could, of course, introduce safe-harbour rules that expressly protect customer funds without specifying under what private law arrangement they are considered protected. But this would raise uncomfortable questions, if, for example, a Provider identified and ring-fenced the funds, but did not fulfil all formal requirements (under regulatory provisions or private law). In that case, should the court rely on substance, and conclude that customers deserve protection, or on formal requirements under regulatory provisions, and leave customers unprotected? Regulatory provisions do not come with clear guidance for hard cases, and introducing specific insolvency provisions without relying on existing private law categories is not a sound long-term strategy. Insolvency courts should be able to make sense of all provisions taken together, and the more exceptions that exist without clear justification, the more sophisticated the courts need to be.

A regulatory approach constitutes a fundamental step towards ascertaining the Provider/custodian duties in e-money services. ${ }^{112} \mathrm{We}$ argue that to be really effective, such rules should be seamlessly connected with private law institutions and contract provisions. Otherwise, they will (a) fail to address new situations, thereby requiring new reforms at best, or leading to the ossification of the system at worst; and (b) introduce restrictions on competition between different e-money models. This is especially true if financial rules

\footnotetext{
${ }^{111}$ In the case In re Lehman Brothers International (Europe) (In Administration), [2012] UKSC 6 the UK Supreme Court decided that a trust arose as a result of the application of statutory provisions (in transposition of Directive 2004/39/EC (MiFID) only after a lengthy process, and careful argumentation. Furthermore, the decision that, in addition to a trust, the specific recovery procedure envisaged by the rules protected all clients' moneys was adopted by a 3-2 majority. The two dissenting judges (Walker and Hope) argued that, in spite of statutory intent, there was no way that property law and trust law could be stretched to encompass funds that had not been actually segregated (and, also, that this left all clients without a high degree of protection).

${ }^{112}$ In Britain the vast body of trust law is supplemented by very specific rules that regulate financial companies' duties for handling customers' money. See, eg Financial Conduct Authority (FCA), The FCA's role under the Payment Services Regulations 2009.
} 
introduce a bank-bias, which can place the MNO-led model in a particularly precarious position.

Given this conclusion there is no reason for us to stop at regulatory provisions when analysing the "certainty versus rigidity" dimension. All rules, both public and private, can be subject to the same scrutiny. Under this premise what matters is how easily the legal rules and institutions can fit together, and be used as "building blocks" to give support to e-money. The issue is not qualitatively different from the interoperability of technologies: if legal rules are compatible, network effects are enhanced and the value of the network increases.

In a context of great uncertainty, it may make sense for the law to "standardize" some options, especially in the initial stages, but policy-makers should be aware of the costs of standardization, leave room for competition, and enhance network effects by allowing different models (based on different institutional structures) to operate with each other.

Cross-border payments, in particular, can only occur if protocols and standards (including legal standards) are compatible. Obstacles to this will exist if, for example, the rules that grant protection to customer funds require (a) the Provider to be a certain type of entity, or be authorized by the domestic regulator; (b) the Provider to employ a specific private law mechanism to safeguard funds; or (c) the Provider to have the assets subject to custody arrangements under the laws of the country.

This requires a second closer look at the use of fiduciary transactions. Many civil law countries, despite contemplating the fiducia as a private law institution, introduce the requirement that only financial institutions can be fiduciaries. ${ }^{113}$ This makes the fiduciary approach half-regulatory, half-private law. It also means that ensuring fund isolation in emoney in those countries will be difficult unless a financial institution is enlisted into the

${ }^{113}$ See note 52 above. 
scheme. This poses problems for the MNO-led model. If the law requires the fiduciary to be a financial institution the options are to (a) not use the fiduciary transaction, in which case the protection of funds via a deposit/loan would be precarious in case of the Provider's insolvency; or (b) rely on fiduciary transactions involving a financial institution, in which case there would be a problem with the characterization of the Provider's role. Should the provider be the beneficiary, or only the agent subscribing fiduciary contracts on behalf of customers?

In this second case, problems can arise with the compatibility of the laws of fiduciary transactions and the laws of mandate. If laws on fiduciary transactions are not flexible, and contemplate a direct fiduciary relationship between the fiduciary (the bank) and the beneficiary, and the Provider adopts the role of an agent, the protection of that Provider's position would be weak. This would impair the model of MNO-as-Provider and contribute to the "bankarization" of e-money. ${ }^{114}$ However, if the Provider acts as the beneficiary, customers would be protected in the event of the bank's insolvency, but not that of the Provider. Thus, restricting the role of the fiduciary to a subset of institutions is not a good idea if the goal is to promote compatibility of rules and competition. To promote safety it would be better to legislate safekeeping characteristics that the fiduciary needs to fulfil, and the contents of the duty to account.

Even if a country does not restrict the fiduciary's role to financial institutions other rigidities can exist. Patrimonial separation may make it easy to insulate the funds, but make it more difficult to grant customers rights over them. ${ }^{115}$ Also, the introduction of fiduciary transactions via statutory reform is an important first step, but does not automatically create

\footnotetext{
${ }^{114}$ This would not need to occur if the law, for example, requires the rendering of e-money services via a separate entity subject to a special authorization akin to that of banks. MNOs could set up such special subsidiary if the laws on significant shareholdings on financial institutions do not pose any problem. Still, it would arguably increase costs for non-bank institutions.

${ }^{115}$ For example, in Italy the patrimony of destination is a device given to companies to create segregated pools of assets. See arts $2447 \mathrm{bis}$ et seq Italian Codice civile. These provisions stipulate the rules for patrimonial separation, but say nothing about the attribution of property/security rights over those assets to specific parties.
} 
the body of principles that serve as background criteria for hard cases. If the principles underlying such rules are not completely clear, judges may search for solutions in adjacent property/security rights, such as the pledge, which may be unsuitable for mobile e-money purposes.

The issue can be even more complex in a cross-border context. Customers seeking protection of their funds in a scenario where the fiduciary is located outside their territory may need, as a prior step, the recognition of patrimonial separation by the laws of a country different from the laws of the country under which the rights were created. Some institutions, like the mandate, are flexible enough, and widespread enough, to enjoy cross-border recognition (it should not be difficult for the courts of one country to recognize a foreign entity as the agent of a customer located in their territory).

But fiduciary transactions are something new and, arguably, an exception. Thus, the question is whether, by enacting statutory provisions that regulate fiduciary transactions a jurisdiction is committed to give recognition to fiduciary transactions created under the laws of a different country, which may entail different rights and duties. A court confronted with a request for the recognition of the patrimonial separation resulting from a fiduciary transaction subject to foreign law may (a) adopt a pragmatic stance, and acknowledge every transaction that is validated as such by a registry entry or legal opinion in the foreign country; (b) rely on the nomen iuris, and recognize it if it is denominated as fiducia or something similar; or (c) subject it to a test of functional equivalence (to see if all the elements considered relevant by its domestic law are present). If the recognition is sought in a country that does not recognize fiduciary transactions under its domestic law, the problem may be even more difficult. The Hague Trusts Convention was supposed to resolve these cross-border problems but has been ratified by few States. ${ }^{116}$

${ }^{116}$ See note 40 . 
Thus, the suitability of fiduciary transactions should not allow us to overlook the associated rigidities. Such rigidities will be present not only in the extreme case where the Provider goes insolvent, but also in cases where the customer wants to make its e-money units "portable", or usable in different countries. Fund protection should be the same across borders, and not lose strength with every degree of separation. Thus, the legal device employed needs to be carefully considered when building the "infrastructure" for fund safeguarding and fund management between Providers and banks beyond the specific agreement between customers and Providers.

\section{Other Variables Shaping Regulation of E-money: Supervisory Capacity and}

\section{Customers' Vulnerability}

In considering strategies to implement e-money systems within their territory lawmakers should be aware of the different legal mechanisms that serve as alternatives (see Section III). They should also place those legal mechanisms within a wider regulatory context and be aware of how different rules interact to enhance certainty and to avoid hindering competition (see Section IV.A). In this final sub-section, we explore other variables that will shape the capacity of policy-makers to regulate e-money: supervisory resources (1) and customers' vulnerability and ability to discern between options (2).

\section{Supervisory capacity}

The first of these restrictions is of great importance to assess the feasibility of certain models. Where resources are constrained, regulators may want to consider ex ante supervision through licensing, as well as off-site supervision through reports, licensing/authorizations, ${ }^{117}$ or the possibility of supervisory authorities effectively "delegating" some of their supervisory

\footnotetext{
117 See GSM Association, 'Ringfencing and Safeguard of Customer Money' $<$ http://www.gsma.com/mobilefordevelopment/programmes/mobile-money-for-the-unbanked/safeguard-ofcustomer-money> accessed 15 November 2014.
} 
duties to the private sector. Enhanced supervision models, which rely on the active ex post monitoring of the Providers' performance duties, require more resources. The possibility of public institutions' direct provision of some of the services, such as the management of the accounts, may also need to be evaluated on this basis.

\section{Customers'vulnerability}

Although some of the mechanisms examined herein provide fund isolation protection, regard must be given to the situation and vulnerability of customers in each case. If e-money services are regulated as a fiduciary contract, the effective protection of customers' funds may be subject to customers' ability to recover their funds quickly and inexpensively. The fact that many customers live in rural areas and without easy access to technology could hinder effective protection.

Additionally, delays in insolvency proceedings and the associated high legal costs can critically weaken the effectiveness of fund isolation protection. It is important for legislatures to explore not only whether customers have an insolvency protection, but whether customer funds can be separated from the insolvent estate.

\section{CONCLUSION}

The mobile money industry is growing quickly and has the potential to improve the lives of many people in developing countries. As the industry develops, the need to protect customers' funds becomes more acute, particularly given the vulnerability of a great proportion of e-money customers.

In Section II we saw that trust law may effectively protect e-money customers' funds in common law jurisdictions. In civil law jurisdictions, however, there are no such clear-cut solutions. To facilitate the inquiry we identified three necessary functions that a legal 
instrument should fulfil to protect customers' funds effectively: a) fund isolation; b) fund safeguarding; and c) protection of customers' interests against operational risks.

Section III demonstrates that the civil law division between Law of Obligations and Law of Property creates important challenges in the quest for a viable alternative to the trust. Proprietary alternatives, such as the law of fiduciary transactions, could provide deficient protection against liquidity and operational risks because some jurisdictions don't adequately regulate fiduciary duties. At the same time, while obligational/contractual alternatives such as the mandate contract do provide a sound regulation of fiduciary duties, they do not provide effective fund isolation. Policy-makers may feel tempted to resort to regulation to bridge the gaps between the two mechanisms, or even to rely on insurance as a fall-back option. However, there are important drawbacks to these direct interventions.

Section IV uses these conclusions to elaborate a broader menu of policy choices. The ideal private law structure would combine fiduciary transactions and mandates by crossreferencing the regimes in statute, or using both mechanisms to fulfil different functions. Specific regulatory intervention could also define the Provider's duties more specifically. The advantages of regulatory intervention, however, should be weighed against its rigidities. Policy makers should give careful consideration to the interaction of new regulation with existing statutes and private law rules: by enhancing certainty through direct intervention regulators could impose a specific model of mobile money services that could hinder competition and cross-border recognition. Finally, issues of regulatory capacity and customer vulnerability should be borne in mind in planning the transition from early to more advanced stages of implementation of e-money. 